\title{
Investigation of Pre-Service Science Teachers' Graphical and Algebraic Understanding of the Concept of Limit
}

\author{
Tuğba Öztürk ${ }^{\mathrm{a}}$ and Neslihan Sönmez \\ ${ }^{a}$ Trabzon University, Fatih Faculty of Education, Trabzon/Turkey (ORCID: 0000-0003-1599-8574) \\ ${ }^{\mathbf{b}}$ Trabzon University, Fatih Faculty of Education, Trabzon/Turkey (ORCID: 0000-0003-1631-9510)
}

Article History: Received: 6 April 2020; Accepted: 10 November 2020; Published online: 8 December 2020

\begin{abstract}
The limit, at the center of almost all subjects of analysis and general mathematics, is also covered in science teaching program. Even though the limit is more important for mathematics to be fully acquired in the mind, it has undeniable importance in different fields of science such as physics, chemistry, and biology. The fact that the concept of limit is mostly taught through graphs and algebraic operations in the general mathematics course instructed in the science teaching program renders it significant to examine pre-service teachers' graphical and algebraic understanding levels. Accordingly, the aim of this study is to examine pre-service science teachers' graphical and algebraic understanding levels concerning the concept of limit. The participants of the study are pre-service teachers in the first year of a science teaching program. Data were collected through an open-ended exam. The data were analyzed by graphical and algebraic understanding categorical scoring charts and are presented based on frequencies and percentages for indicators of each understanding level. The study found the pre-service teachers' graphical understanding of the concept of limit to be higher than their algebraic understanding. We think that the results obtained in this study will give faculty members an idea about teaching practices related to the concept of limit.
\end{abstract}

Keywords: limit, understanding levels, graphical understanding, algebraic understanding, pre-service teachers.

DOI: $10.16949 /$ turkbilmat.715262

Öz: Analiz ve genel matematiğin neredeyse bütün konularının merkezindeki limit, eğitim fakültelerinin lisans programlarından biri olan fen bilgisi öğretmenliğinde de yer almaktadır. Limit soyut kavramların zihinde yer edinebilmesinde matematik için önemli görülse de fizik, kimya, biyoloji gibi fen bilimlerinin farklı alanlarında da limitin önemi yadsınamaz. Limit kavramının fen bilgisi öğretmenliği programında yürütülen genel matematik dersinde daha çok grafikler ve cebirsel işlemler üzerinden öğretilmesi, öğretmen adaylarının grafiksel ve cebirsel anlama düzeylerinin incelenmesini anlamlı kılmaktadır. Bu doğrultuda çalışmanın amacı, fen bilgisi öğretmen adaylarının limit kavramına yönelik grafiksel ve cebirsel anlama düzeylerinin incelenmesidir. Araştırmanın katılımcıları, fen bilgisi öğretmenliği programının birinci sınıfında öğrenim gören öğretmen adaylarıdır. Veri toplama aracı açık uçlu bir sınavdır. Veriler, grafiksel ve cebirsel anlama kategorik puanlama cetvelleriyle analiz edilerek her bir anlama düzeyinin göstergelerine yönelik frekans ve yüzdeler aracılığıyla sunulmuştur. Araştırmanın sonucunda öğretmen adaylarının limit kavramına yönelik grafiksel anlamalarının cebirsel anlamalarına göre üst düzeyde olduğu belirlenmiştir. Araştırmadan elde edilen sonuçların limit kavramına yönelik öğretimdeki uygulamalara dair öğretim üyelerine fikir vereceği düşünülmektedir.

Anahtar Kelimeler: Limit, anlama düzeyi, grafiksel anlama, cebirsel anlama, öğretmen adayı.

Türkçe sürüm için tıklayınız

\section{Introduction}

Mathematics plays an important role in our daily lives by helping us solve many problems we face and making our lives easier (Davis, Hersch, \& Marchisotto, 2015). One of the prerequisites for having a profession that allows leading a qualified life is to have a certain level of mathematical knowledge. This means that science, social sciences, and health sciences require the use of mathematics from basic to advanced level. Therefore, it is indispensable to use mathematical concepts' knowledge and operations in an efficient way both in trade, engineering, and in basic sciences (Travers \& Westbury, 1989). The fact that mathematics classes are included in all undergraduate programs of many faculties in university education supports this.

During undergraduate education, classes under the names of "analysis" and "general mathematics" are taught, and various mathematical concepts are addressed in such classes. Set, correlation, function, limit, continuity, derivative, and integral are among these basic concepts. These mathematical concepts are connected to each other just like a chain ring (Dede \& Argün, 2004; Öztürk, 2016). In other words, any concept is shaped by being built on the foundation formed by previous concepts (O'Halloran, 2015). The limit is one of the important concepts that form the basis for shaping the concepts of continuity, derivative, and integral (Arslan \& Çelik, 2013; Cornu, 2002, N. Çetin, 2009). The concept of limit is used in many situations such as calculation of the area by increasing the number of edges of the regular polygon placed in the circle (Ministry of National 
Education [MNE], 2005), determination of the asymptotes of functions, calculation of the sum of geometric series (Parameswaran, 2007), and creation of derivative and integral definitions (Cornu, 2002; Denbel, 2014). In this respect, it can be said that if the concept of limit is not effectively learned, the knowledge obtained later in analysis or general mathematics classes will not be at a satisfactory level (Arslan \& Çelik, 2013; Lee, 1992; Özmantar \& Yeşildere, 2013).

The limit, which is at the center of almost all subjects of analysis and general mathematics, is also covered in science teaching, one of the undergraduate programs of faculties of education. Even though the limit is more important for mathematical concepts to be fully acquired in the mind, it has undeniable importance in different fields of science such as physics, chemistry, and biology. For instance, calculating the pressure value at a point in the field of physics, estimating the sustainable population in the field of biology, and maintaining thermodynamic equilibrium in the field of chemistry are related to the concept of limit. In this respect, there is a need to form a basis for the concept of limit in science classes, even if at a basic level. A science teacher needs to have sufficient levels of knowledge and skills in each one of physics, chemistry, and biology fields (Akpinar \& Ergin, 2004; Bardak \& Karamustafaoğlu, 2016) besides basic knowledge of the function and the concept of limit that describes the behavior of the function around a certain point. The concept of limit is addressed within the scope of the general mathematics course taught in the science teaching program. In this course, the formal definition of the limit (the definition $\varepsilon-\delta$ ) is not given; instead, the intuitive definition is included. Intuitive definition of the limit is discussed as follows: "Let's assume that a function $f$ is defined for all $x$ values that are in the neighborhood of point $x_{o}$ (it does not have to be defined at point $x_{o}$ ). If $f(x)$ approaches a real number $L$ when $x$ approaches $x_{o}$ sufficiently close, then the limit of $f(x)$ is expressed as $L$ and represented by $\lim _{x \rightarrow x_{o}} f(x)=L$ when $x$ goes to $x_{o}$ " (Ertem-Akbaş, 2016).

Understanding mathematical concepts involves a hierarchical structure. There are various levels of understanding in the learning of geometry and analysis concepts by students. While Van Hiele (1957) defines levels of understanding geometry concepts, Fless (1988) and Lee (1992) provide levels of understanding analysis concepts. Lee (1992), who determined various levels of understanding the limit, which is an analysis concept, took Fless' (1988) understanding levels, which address the derivative along with the limit, as basis. However, Lee (1992) examined understanding levels more deeply through a single concept by focusing only on the concept of limit. Lee (1992) defined levels of understanding the concept of limit as basic level, computational level, transitional level, rigorous level, and abstract level. At the basic level, the existence or absence of the limit of a function or series can be determined by assigning numerical values or graphically, without the formal definition of the limit. At the computational level, the limit of a function or series is determined by using the properties required by the limit. Due to the nature of this level, algorithmic operations are performed without resorting to the formal definition. At the transitional level, the notation and terminology contained in the definition $\varepsilon-\delta$ of the limit can be explained both verbally and graphically. This level also requires competence to decide in which situations some basic theorems can be used. At the rigorous level, proofs of the propositions related to the limit can be made besides the competences required by the first three levels. The abstract level requires an awareness of the importance of the role of the limit in mathematics and the ability to make generalizations by applying the definition of the limit to spaces of different dimensions, in addition to the competences related to the previous levels. The first two of these levels involve a basic level of interpretation mostly through graphical and algebraic operations without using the formal definition of the limit. The other three levels are expected to be attained during the process of specialization in mathematics. Elia, Gagatsis, Panaoura, Zachariads and Zoulinaki (2009) state that the limit is one of the basic concepts that combine algebraic and geometric representations and emphasize the importance of using both representations in teaching for the full understanding of this concept. However, the fact that pre-service science teachers learn the concept of limit mostly through graphs and algebraic operations in the general mathematics course renders it significant to examine their graphical and algebraic understanding levels. This study focuses on the basic level and computational level from the comprehension levels of the limit concept. Considering the definitions made by Lee (1992) for comprehension levels, the basic level was examined from the "graphical understanding" perspective and the computational level from the "algebraic understanding" perspective.

The literature includes many studies on the concept of limit (Baki \& Çekmez, 2012; Baştürk \& Dönmez, 2011; Biber \& Argün, 2015; Çı1dır, 2012; Denbel, 2014; İ. Çetin, 2009; Kepçeoğlu \& Yavuz, 2016; Lee, 1992; N. Çetin, 2009; Parameswaran, 2007; Tall \& Vinner, 1981; Williams, 1991, etc.). These studies generally focus on the effect of learning environment design on learning the concept of limit, student understanding of the formal definition of the limit, and misconceptions about the limit and the continuity. In addition, most of the studies were conducted with pre-service mathematics teachers. Lee (1992) evaluated pre-service high school mathematics teachers' understanding of the limit in terms of some components of pedagogical content knowledge. Baki and Çekmez (2012) examined pre-service primary school mathematics teachers' understanding of the formal definition of the limit. Kepçeoğlu and Yavuz (2017) conducted an experimental study and aimed to examine the effect of teaching the limit and the continuity through GeoGebra software on the success of pre- 
service mathematics teachers. That study focused on determining the effect of a learning environment on learning the concept of limit. Unlike other researchers, Biber and Argün (2015) conducted a study on how the concept of limit of two-variable functions is constructed by pre-service mathematics teachers. As to the studies on misconceptions, Baştürk and Dönmez (2011) focused on the misconceptions of pre-service mathematics teachers about the limit and the continuity, while Çıldır (2012) focused on the misconceptions of pre-service physics teachers about the concept of limit. Çıldır (2012) collected the opinions of pre-service teachers about the teaching of the general mathematics course included in the physics teaching program. When previous studies are taken into consideration, it is understood that there are few studies examining the intuitive and algebraic understanding of the concept of limit of a study group other than pre-service mathematics teachers. The fact that there is a small number of studies on graphical and algebraic understanding and that the studies carried out on the basis of the concept of limit were mostly conducted with pre-service mathematics teachers point to a need for a study in this field. In this context, the aim of this study is to examine pre-service science teachers' graphical and algebraic understanding levels concerning the concept of limit. The research problem of the study is as follows: "What are the graphical and algebraic levels of understanding of pre-service science teachers for the concept of limit?". This descriptive study may contribute to faculty members in the formation of the general mathematics course content in order to provide a better understanding for pre-service teachers in major area courses (physics, chemistry, and biology) that require using the concept of limit.

\section{Method}

This research, which aims to examine the graphical and algebraic understanding of the concept of limit of pre-service science teachers who have taken the general mathematics course, is a descriptive study. Descriptive studies are studies in which no intervention is made by researchers to the facts or events studied (Sönmez \& Alacapınar, 2014). Descriptive studies, which are conducted with the aim of revealing the 'what' of the phenomenon and the event without any intervention, do not have any attempt to change or develop the current situation. The concept of limit is one of the concepts in the science teaching program within the scope of general mathematics lesson. In this study, pre-service science teachers' understanding of the concept of limit was examined at the end of the semester. The lessons were conducted within the weekly program. Therefore, no instructional intervention was made by the researchers to the pre-service science teachers to examine their comprehension levels. The present phenomenon of the study is the graphical and algebraic learning levels of the pre-service teachers. In order to determine this phenomenon, an open-ended exam was applied to the pre-service teachers and their level of comprehension was determined by considering the answers given to this exam. From this point of view, it was tried to reflect the graphical and algebraic understanding of the pre-service teachers towards the limit concept from a descriptive perspective holistically.

\subsection{Study Group}

The participants of the study were 82 first-grade pre-service teachers studying in a science teaching program at a state university. These pre-service teachers included all students taking the general mathematics 1 course and studying in two different sections. Purposeful sampling method, one of the improbable sampling types, was used in determining the participants. Purposeful sampling is based on the assumption that it is necessary to choose a sample from which a lot of things can be learned about an event or phenomenon that is desired to be discovered and understood (Merriam, 2015). The study group was chosen from among pre-service science teachers because in the general mathematics course taught in the science program, the concept of limit is taught at a basic level for graphical and algebraic understanding, in parallel with the purpose of the study.

\subsection{Data Collection Tool}

An open-ended exam consisting of a total of 6 questions was used to determine the pre-service teachers' graphical and algebraic understanding of the concept of limit. Table 1 provides a graphical and algebraic classification of the questions in the exam and provides explanations about the questions.

Some of the open-ended questions used in the study are the graphical or algebraic form of the same question. In this respect, the first and fourth questions, which were intended to determine graphical understanding, were transformed into a form to determine algebraic understanding in the second and third questions, respectively. We did so mainly because we thought it would facilitate the comparison of the pre-service teachers' graphical and algebraic understanding. An exemplary pair of questions demonstrating such transformation is given in Figure 1. 
Table 1. Explanations on the Content of the Questions

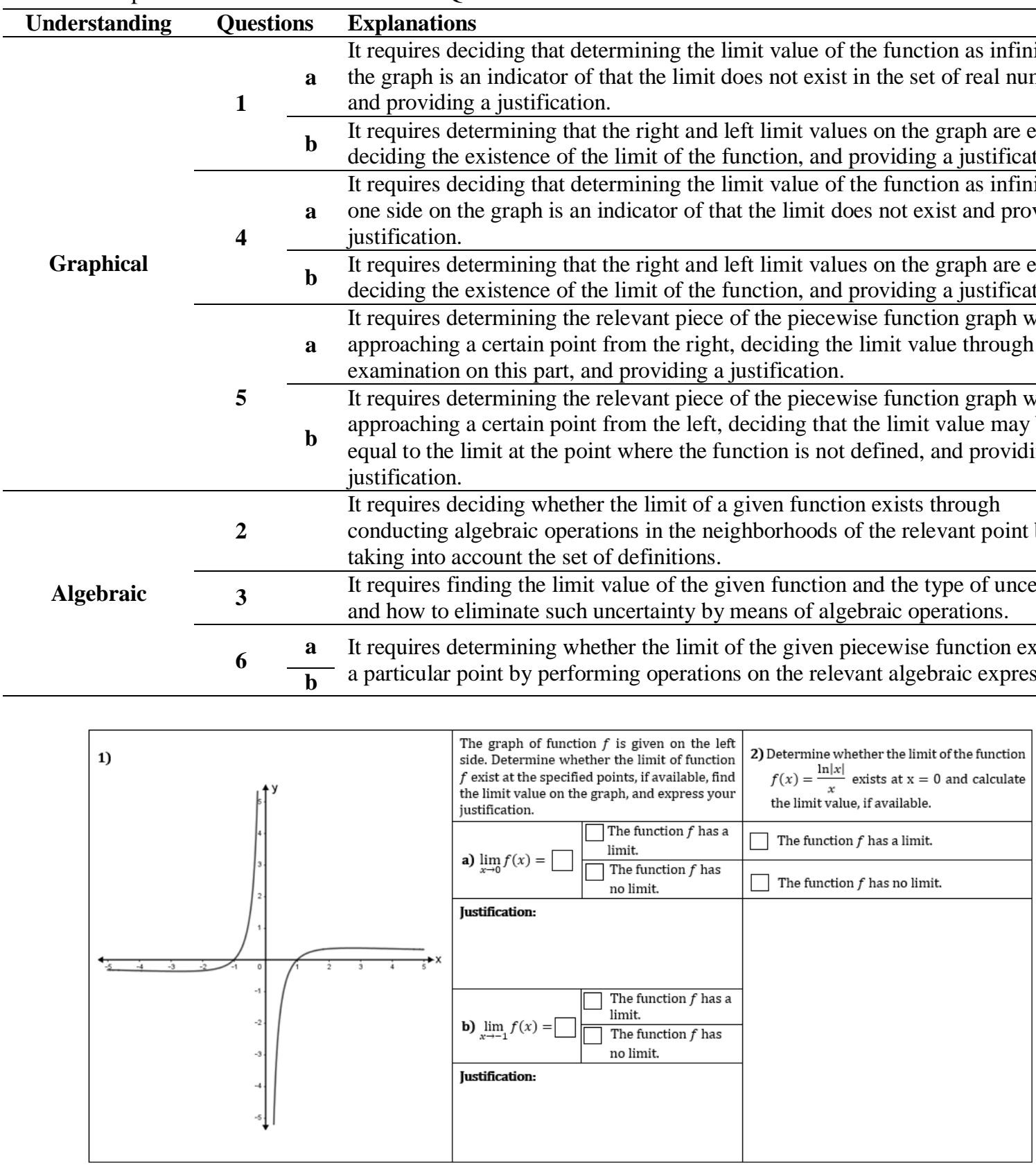

Figure 1. Equivalent questions to determine graphical and algebraic understanding

Three points were considered in the development of the open-ended exam, which is used as a data collection tool. The first of these is that the questions in the exam fully cover the content of the limit concept. Second, the questions allow to provide justifications for situations related to the limit concept (e.g., the existence of the limit, finding limits from the right and left, etc.). Third, the questions allow comparison in terms of graphical and algebraic understanding. While performing the first and second issues, misconceptions regarding the limit concept were also taken into consideration. The third point explains the use of the questions that are transformed into algebraic form for determining graphical understanding in determining algebraic understanding. Considering these situations, firstly, each author suggested questions. Afterwards, a draft form was created to ensure the content validity by examining the questions and the draft form of the questions was examined by an expert. After taking expert opinions, the questions were edited, the process was repeated, and the final version of the questions was prepared and made ready for the open-ended exam.

A pilot study was conducted in order to see the problems that may arise during the implementation of the data collection tool, to determine the validity and reliability of this tool, and to decide how to follow the analysis of the data. The pilot study was applied to fourth grade students studying in a mathematics education program. As a result of the pilot study, it was decided that it would be appropriate to use different questions to determine graphical and algebraic understanding in piecewise functions. This is because when the graph of the piecewise 
function and the algebraic expression of this function are given in two different questions, students may directly realize that they are two different forms of the same question. Accordingly, the functions mentioned in the last two questions were arranged as two different piecewise functions. The basic element that makes these questions equivalent is the piecewise function. However, requesting a justification along with the solution was decided to be unnecessary in the last question (Q6) associated with algebraic understanding. This is because the justification that is expected to be provided is already expressed through algebraic operations in solution steps. As a result, the data collection tool has been made applicable for the actual implementation. In addition, with the pilot study, the negligence of the situations that may arise in the categorical scoring charts developed for the analysis of the data was prevented. Besides, the pilot study also guided the research in determining the implementation time of the data collection tool.

\subsection{Data Analysis}

The data obtained from the exam were analyzed through graphical and algebraic understanding categorical scoring charts. These categorical scoring charts, developed by the researchers, contain indicators for determining the graphical and algebraic understanding of pre-service teachers regarding the concept of limit. Besides the student responses obtained through the pilot study, the literature (Lee, 1992) was also taken into consideration while determining the indicators. By this means, the basic indicators of the concept of limit for graphical and algebraic understanding were decided. These basic indicators include "deciding the existence of the limit", "expressing the limit value", "providing a justification", and "performing algebraic operations". Although the indicators related to graphical and algebraic understanding levels were generally shaped around similar components, the different nature of graphical understanding and algebraic understanding led to the development of two separate categorical scoring charts. Accordingly, while "providing a justification" was one of the indicators relevant to the nature of graphical understanding level, "performing algebraic operations" was one of the indicators relevant to the nature of algebraic understanding level. The indicators in the scoring charts were finalized by adding new indicators to cover all possible situations in the student responses obtained through the pilot study. The understanding levels in the scoring charts are sub-category levels of graphical understanding examined from the basic level perspective and algebraic understanding examined from the operational level perspective. The sub-category levels of graphical understanding (GU0, GU1, GU2, GU3, GU4) and sub-category levels of algebraic understanding (AU0, AU1, AU2, AU3, AU4) were determined by considering all possible answers that could be given by the pre-service teachers to the questions in the open-ended exam. The responses given by the pre-service teachers were scored from zero (0) points to four (4) points, which taking into account the scoring chart. For example, a pre-service teacher -who made a "correct" decision on the existence of the limit, expressed the limit value as "incorrect" and gave a "partly" justification in the question Q1 asked to determine the graphical understanding level- received "2" points due to the fact that he/she was at the GU2 level. While the understanding levels were examined separately, frequency and percentage distributions were only presented. In the process of comparing the graphical and algebraic understanding levels, the pre-service teachers' total scores were taken into account. "Graphical Understanding Categorical Scoring Chart" used for data analysis is given in Table 2.

Table 2. Graphical Understanding Categorical Scoring Chart

\begin{tabular}{|c|c|c|c|c|c|c|c|c|c|}
\hline \multicolumn{3}{|c|}{ Question } & \multicolumn{3}{|c|}{ Q1 and Q4 } & \multicolumn{2}{|c|}{ Question } & \multicolumn{2}{|c|}{ Q5 } \\
\hline \multirow{2}{*}{ Category } & \multicolumn{2}{|c|}{ Indicator } & \multirow{2}{*}{$\begin{array}{c}\text { Deciding } \\
\text { the } \\
\text { existence } \\
\text { of the } \\
\text { limit }\end{array}$} & \multirow{2}{*}{$\begin{array}{c}\text { Expressing } \\
\text { the limit } \\
\text { value }\end{array}$} & \multirow{2}{*}{$\begin{array}{l}\text { Providing a } \\
\text { justification }\end{array}$} & \multicolumn{2}{|c|}{ Indicator } & \multirow{2}{*}{$\begin{array}{c}\text { Expressing } \\
\text { the limit } \\
\text { value }\end{array}$} & \multirow{2}{*}{$\begin{array}{l}\text { Providing a } \\
\text { justification }\end{array}$} \\
\hline & \multicolumn{2}{|c|}{ Level } & & & & \multicolumn{2}{|c|}{ Level } & & \\
\hline \multirow{10}{*}{ 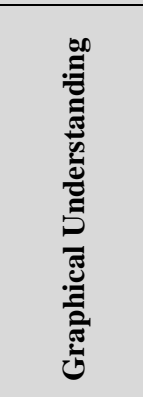 } & \multirow{2}{*}{ GU0 } & $\mathbf{a}$ & No answer & No answer & No answer & \multirow{2}{*}{ GU0 } & $\mathbf{a}$ & No answer & No answer \\
\hline & & b & Incorrect & Incorrect & Incorrect/No & & b & Incorrect & Incorrect/No \\
\hline & \multirow{4}{*}{ GU1 } & $\mathbf{a}$ & Correct & Incorrect & Incorrect/No & \multirow{4}{*}{\multicolumn{2}{|c|}{ GU1 }} & \multirow{4}{*}{ Incorrect } & \multirow{4}{*}{ Partly } \\
\hline & & b & Incorrect & Correct & Incorrect/No & & & & \\
\hline & & c & Correct & Correct & Incorrect/No & & & & \\
\hline & & d & Incorrect & Incorrect & Partly & & & & \\
\hline & \multirow{2}{*}{ GU2 } & $\mathbf{a}$ & Correct & Incorrect & Partly & \multirow{2}{*}{\multicolumn{2}{|c|}{ GU2 }} & \multirow{2}{*}{ Correct } & \multirow{2}{*}{ Incorrect/No } \\
\hline & & b & Incorrect & Correct & Partly & & & & \\
\hline & GU3 & $\mathbf{a}$ & Correct & Correct & Partly & GU3 & & Correct & Partly \\
\hline & GU4 & b & Correct & Correct & Adequate & GU4 & & Correct & Adequate \\
\hline
\end{tabular}

"Algebraic Understanding Categorical Scoring Chart" used for data analysis is given in Table 3. 
Table 3. Algebraic Understanding Categorical Scoring Chart

\begin{tabular}{|c|c|c|c|c|c|c|c|c|c|}
\hline \multicolumn{3}{|c|}{ Question } & \multicolumn{3}{|c|}{ Q2 and Q6 } & \multicolumn{2}{|c|}{ Question } & \multicolumn{2}{|c|}{ Q3 } \\
\hline \multirow{2}{*}{ Category } & \multicolumn{2}{|c|}{ Indicator } & \multirow{2}{*}{$\begin{array}{c}\text { Deciding } \\
\text { the } \\
\text { existence } \\
\text { of the limit }\end{array}$} & \multirow{2}{*}{$\begin{array}{l}\text { Expressing } \\
\text { the limit } \\
\text { value }\end{array}$} & \multirow{2}{*}{$\begin{array}{l}\text { Performing } \\
\text { algebraic } \\
\text { operation }\end{array}$} & \multirow{2}{*}{\multicolumn{2}{|c|}{$\begin{array}{c}\text { Indicator } \\
\text { Level }\end{array}$}} & \multirow{2}{*}{$\begin{array}{c}\text { Expressing } \\
\text { the limit } \\
\text { value }\end{array}$} & \multirow{2}{*}{$\begin{array}{l}\text { Performing } \\
\text { algebraic } \\
\text { operation }\end{array}$} \\
\hline & Lev & & & & & & & & \\
\hline \multirow{16}{*}{ 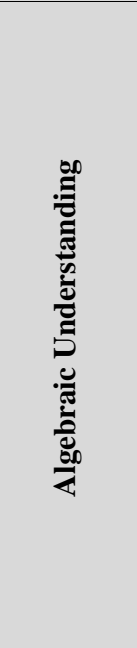 } & \multirow{4}{*}{ AUO } & $\mathbf{a}$ & No answer & No answer & No answer & \multirow{4}{*}{ AUO } & \multirow{2}{*}{$\mathbf{a}$} & \multirow{2}{*}{ No answer } & \multirow{2}{*}{ No answer } \\
\hline & & b & Incorrect & Incorrect & No & & & & \\
\hline & & c & Incorrect & Incorrect & Incorrect & & \multirow{2}{*}{ b } & \multirow{2}{*}{ Incorrect/No } & \multirow{2}{*}{ Incorrect } \\
\hline & & d & Correct & Incorrect & No & & & & \\
\hline & \multirow{5}{*}{ AU1 } & $\mathbf{a}$ & Correct & Correct & No & \multirow{5}{*}{ AU1 } & & \multirow{5}{*}{ Correct } & \multirow{5}{*}{ Incorrect } \\
\hline & & b & Correct & Incorrect & Incorrect & & & & \\
\hline & & c & Incorrect & Correct & Incorrect & & & & \\
\hline & & d & Correct & Correct & Incorrect & & & & \\
\hline & & e & Incorrect & Incorrect & Partly & & & & \\
\hline & \multirow{3}{*}{ AU2 } & $\mathbf{a}$ & Incorrect & Incorrect & Correct & \multirow{3}{*}{\multicolumn{2}{|c|}{ AU2 }} & \multirow{3}{*}{ Incorrect/No } & \multirow{3}{*}{ Partly } \\
\hline & & b & Incorrect & Correct & Partly & & & & \\
\hline & & c & Correct & Incorrect & Partly & & & & \\
\hline & \multirow{3}{*}{ AU3 } & $\mathbf{a}$ & Correct & Correct & Partly & \multirow{3}{*}{ AU3 } & \multirow{2}{*}{$\mathbf{a}$} & \multirow{2}{*}{ Correct } & \multirow{2}{*}{ Partly } \\
\hline & & b & Incorrect & Correct & Correct & & & & \\
\hline & & c & Correct & Incorrect & Correct & & b & Incorrect & Correct \\
\hline & \multicolumn{2}{|l|}{ AU4 } & Correct & Correct & Correct & AU4 & & Correct & Correct \\
\hline
\end{tabular}

Frequency and percentages were determined for the indicators of each understanding level through analysis of the data based on the categorical scoring charts. The pre-service teachers' graphical and algebraic understanding levels were compared over such frequencies and percentages.

\subsection{Validity and Reliability}

Validity and reliability in this study were carried out on three cases as data collection tool, categorical scoring chart, and data analysis. As validity and reliability of the data collection tool, the open-ended exam was created to include the whole scope of the limit concept. Thus, the questions of this exam are associated with the intuitive definition of the limit, right and left limit, infinite limits, algebraic operations and theorems related to the limit. However, it was confirmed that the questions were suitable for determining the graphical and algebraic understanding of the concept of limit by the opinion of an expert who is a mathematics educator. The opinions of the expert were taken several times. Thus, a repetitive process was carried out for validity and reliability. As part of the validity and reliability of categorical scoring charts, the opinions of an expert were taken after the charts were developed as a result of the literature review. In accordance with these opinions, the indicators were presented in a structure that would make them easier to notice rather than expressed in text. This structure also facilitated to analyze the data. For finalizing the scoring charts, a preliminary data analysis was carried out. Thus, possible indicators were prevented to not notice. In data analysis, the researchers coded the data independently to ensure the coding reliability of the data. An $80 \%$ coding agreement was found between the researchers. The researchers made the necessary arrangements by discussing the disagreements in coding.

\subsection{Study Process}

This study, which aimed to examine pre-service science teachers' graphical and algebraic understanding of the concept of limit, was conducted after the pre-service teachers were provided with the required background in the general mathematics course of fall semester of 2017-2018 academic year. The general mathematics 1 course was taught by one of the authors, who was a mathematics educator. While teaching the concept of limit, the meaning of the concept was emphasized through both graphical and algebraic operations. During the process of this course, the meaning of the concept was emphasized through both graphs and algebraic operations. In this respect, a teaching was intended to promote the pre-service teachers' graphical and algebraic understanding in a stable manner. The course was planned and conducted to serve this purpose. The content of this course was shaped depending on three issues to teach the concept of limit. The first is to be lived a process related how the values of a function change in the neighborhood of a certain point for the internalization of the definition of the concept. The second is to examine or confirm the limit of each function on its graphs. The third is to discuss what kind of algebraic operations can be performed to find the limit value of a function and to perform these operations. At the end of the academic year, the pre-service teachers' understanding of the concept of limit was determined through an open-ended exam. The exam lasted approximately 45 minutes, and the pre-service teachers' answers to the questions were taken individually. 


\section{Findings}

The pre-service science teachers' graphical and algebraic understanding levels concerning the concept of limit, and comparison of understanding levels are presented under three sub-titles in this section.

\subsection{Findings Regarding the Pre-Service Science Teachers' Graphical Understanding Levels Concerning the Concept of Limit}

The answers of the pre-service science teachers to the questions aimed at determining their graphical understanding levels were analyzed based on the indicators in the graphical understanding categorical scoring chart. The frequency and percentage distribution obtained through this analysis are presented in Table 4.

Table 4. Frequency and Percentage Distribution of Graphical Understanding Levels

\begin{tabular}{|c|c|c|c|c|c|c|c|c|c|c|c|c|c|c|c|c|c|}
\hline \multirow{2}{*}{\multicolumn{2}{|c|}{ Question }} & \multicolumn{4}{|c|}{ Q1 } & \multicolumn{4}{|c|}{ Q4 } & \multirow{2}{*}{\multicolumn{2}{|c|}{ Question }} & \multicolumn{4}{|c|}{ Q5 } & \multirow{2}{*}{\multicolumn{2}{|c|}{ Total }} \\
\hline & & \multicolumn{2}{|c|}{ Q1 } & \multicolumn{2}{|c|}{ Q1b } & \multicolumn{2}{|c|}{ Q4 } & \multicolumn{2}{|c|}{ Q4b } & & & \multicolumn{2}{|c|}{ Q5 } & \multicolumn{2}{|c|}{ Q5b } & & \\
\hline Leve & & $\mathbf{f}$ & $\%$ & f & $\%$ & f & $\%$ & f & $\%$ & Leve & & $\mathbf{f}$ & $\%$ & f & $\%$ & f & $\%$ \\
\hline \multirow{2}{*}{ GU0 } & $\mathbf{a}$ & 1 & 1.22 & 2 & 2.44 & 3 & 3.66 & 1 & 1.22 & \multirow{2}{*}{ GU0 } & $\mathbf{a}$ & 6 & 7.32 & 9 & 11 & \multirow{2}{*}{106} & \multirow{2}{*}{21.54} \\
\hline & b & 16 & 19.5 & 17 & 20.7 & 7 & 8.54 & 3 & 3.66 & & b & 22 & 26.8 & 19 & 23.2 & & \\
\hline \multirow{4}{*}{ GU1 } & $\mathbf{a}$ & 1 & 1.22 & 21 & 25.6 & 4 & 4.88 & 5 & 6.1 & \multirow{4}{*}{ GU1 } & & \multirow{4}{*}{8} & \multirow{4}{*}{9.76} & \multirow{4}{*}{10} & \multirow{4}{*}{12.2} & \multirow{4}{*}{113} & \multirow{4}{*}{22.97} \\
\hline & b & 0 & 0 & 1 & 1.22 & 0 & 0 & 3 & 3.66 & & & & & & & & \\
\hline & c & 21 & 25.6 & 3 & 3.66 & 20 & 24.4 & 8 & 9.76 & & & & & & & & \\
\hline & d & 3 & 13.66 & 0 & 0 & 1 & 1.22 & 4 & 4.88 & & & & & & & & \\
\hline \multirow{2}{*}{ GU2 } & $\mathbf{a}$ & 1 & 1.22 & 5 & 6.1 & 3 & 3.66 & 1 & 1.22 & \multirow{2}{*}{ GU2 } & & \multirow{2}{*}{14} & \multirow{2}{*}{17.1} & \multirow{2}{*}{12} & \multirow{2}{*}{14.6} & \multirow{2}{*}{37} & \multirow{2}{*}{7.52} \\
\hline & b & 0 & 0 & 0 & 0 & 0 & 0 & 1 & 1.22 & & & & & & & & \\
\hline GU3 & & 29 & 35.4 & 7 & 8.54 & 35 & 42.7 & 27 & 32.9 & GU3 & & 5 & 6.1 & 4 & 4.88 & 107 & 21.75 \\
\hline GU4 & & 10 & 12.2 & 26 & 31.7 & 9 & 11 & 29 & 35.4 & GU4 & & 27 & 32.9 & 28 & 34.1 & 129 & 26.22 \\
\hline
\end{tabular}

As shown in Table 4, the pre-service teachers are concentrated at higher levels in terms of graphical understanding of the limit, with approximately $48 \%$ at the GU3 and GU4 levels. When each level is examined, it is seen that approximately $26 \%$ of the pre-service teachers are at the highest level, GU4, and nearly $22 \%$ are at the GU3 level. When GU0 and GU1 levels are considered, it is noteworthy that about $45 \%$ of the pre-service teachers are concentrated at lower levels in terms of graphical understanding. Therefore, it is evident that the majority of the pre-service teachers have graphical understanding either at higher or at lower levels. A very small proportion, approximately $8 \%$, is at the GU2 level and has moderate graphical understanding.

The pre-service teachers' concentration at the GU4 level in terms of graphical understanding is seen to be due to their answers to the questions Q1b, Q4b, Q5a, and Q5b in the open-ended exam. Figure 2 illustrates a sample solution to Q4b, which a large part of the pre-service teachers (35.4\%) correctly answered in terms of expressing the existence of the limit and providing sufficient justification.

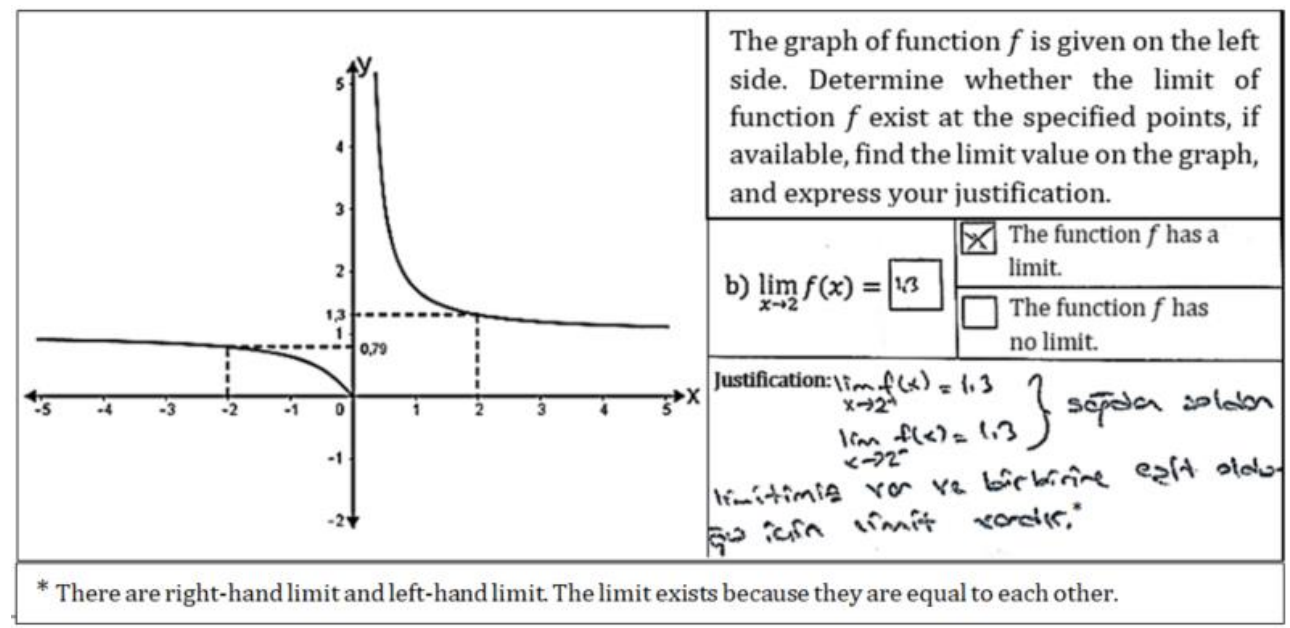

Figure 2. Sample solution at the GU4 level for Q4b

As shown in Figure 2, the pre-service teacher made the right decision for the existence of the limit through examinations from the right and left for the indicated point on the graph. In addition, he correctly expressed the 
limit value and provided a sufficient justification. Thus, he provided a solution relevant to the indicators at the GU4 level.

The answers at the GU3 level mostly (42.7\%) came out in the solution of Q4a. A sample solution for this level is given in Figure 3.

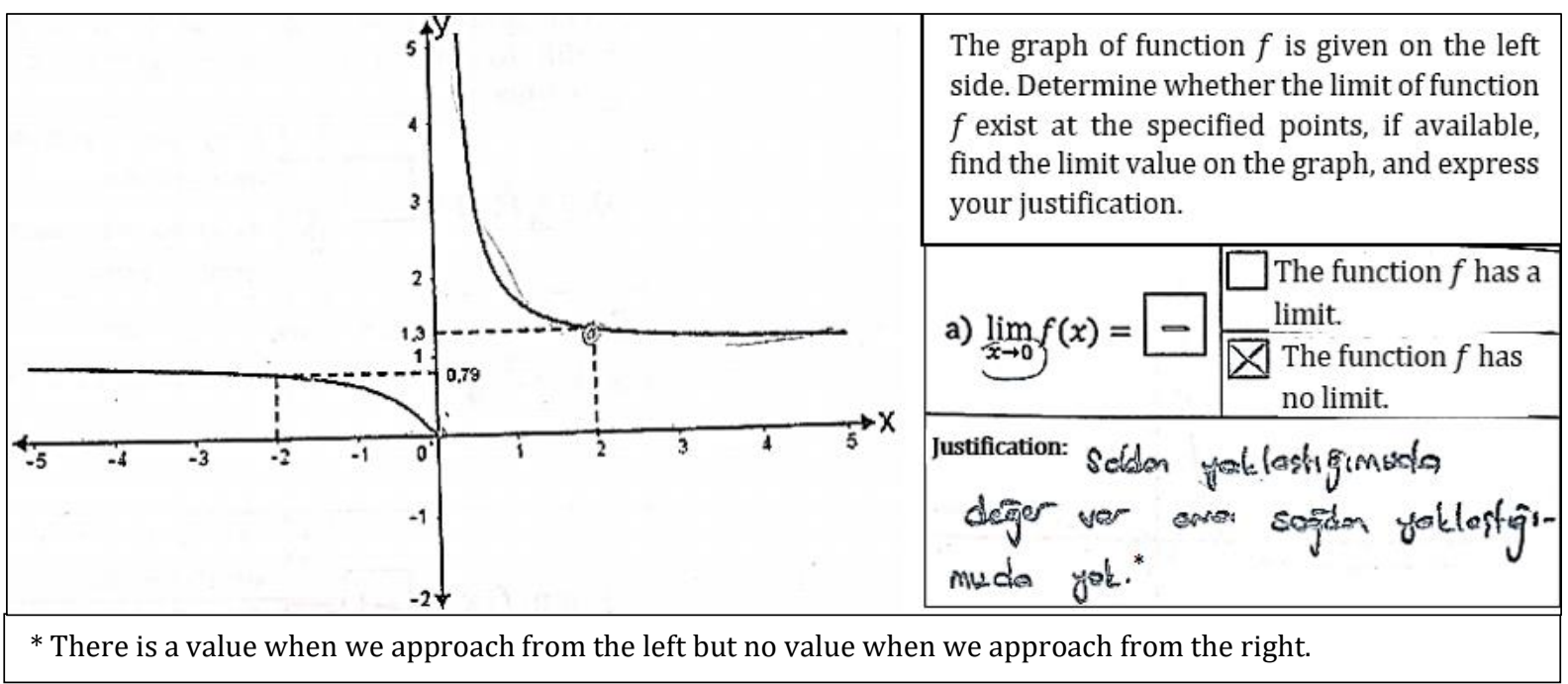

Figure 3. Sample solution at the GU3 level for Q4a

In Figure 3, the pre-service teacher made a right decision about the existence of the limit and stated the correct limit value but provided an insufficient justification. The justification for this solution is insufficient because it does not specify the number that the value it claims to exist when approaching the relevant point from the left is equal to and does not associate the absence of the limit value when approaching from the right with that the result turns out to be infinite.

Q5a and Q5b are the questions where the pre-service teachers are concentrated at the GU0 level. There is also a considerable concentration at this level in Q1a and Q1b, (19.5\% and 20.7\%, respectively). The majority of the pre-service teachers $(25.6 \%)$ answered the same questions at the GU1 level. Figure 4 shows the solutions at the GU0 level of two different pre-service teachers misstating the existence of the limit, the limit value, and the rationale.

\begin{tabular}{ll|l|l|l|l|}
\hline The graph of function $f$ is given on the left side. \\
Determine whether the limit of function $f$ exist \\
at the specified points, if available, find the limit \\
value on the graph, and express your \\
justification.
\end{tabular}

Figure 4. Sample solutions at the GU0 level for Q1a and Q1b 
As shown in Figure 4, in Q1a, the pre-service teacher made a wrong decision about the existence of the limit considering that the limit value of a function in the set of real numbers could be infinite. Furthermore, he could not justify the non-existence of the limit of the function as the results $-\infty$ and $+\infty$ were reached, respectively when the relevant point was approached from the right and left. When the pre-service teacher examined the limit of the function from the right and left at the relevant point on the graph in Q1b, he found the limit values as 1 and $\infty$, respectively, thereby deciding that there was no limit. The expected answer from the pre-service teacher was that the limit exists at the relevant point, and its value is 0 .

The pre-service teachers gave fewest answers at the GU2 level in terms of graphical understanding. The solutions at the GU2 level of the two pre-service teachers who correctly stated the limit value but provided an incorrect justification (Q5a) or provided no justification $(\mathrm{Q} 5 \mathrm{~b})$ are presented in Figure 5.

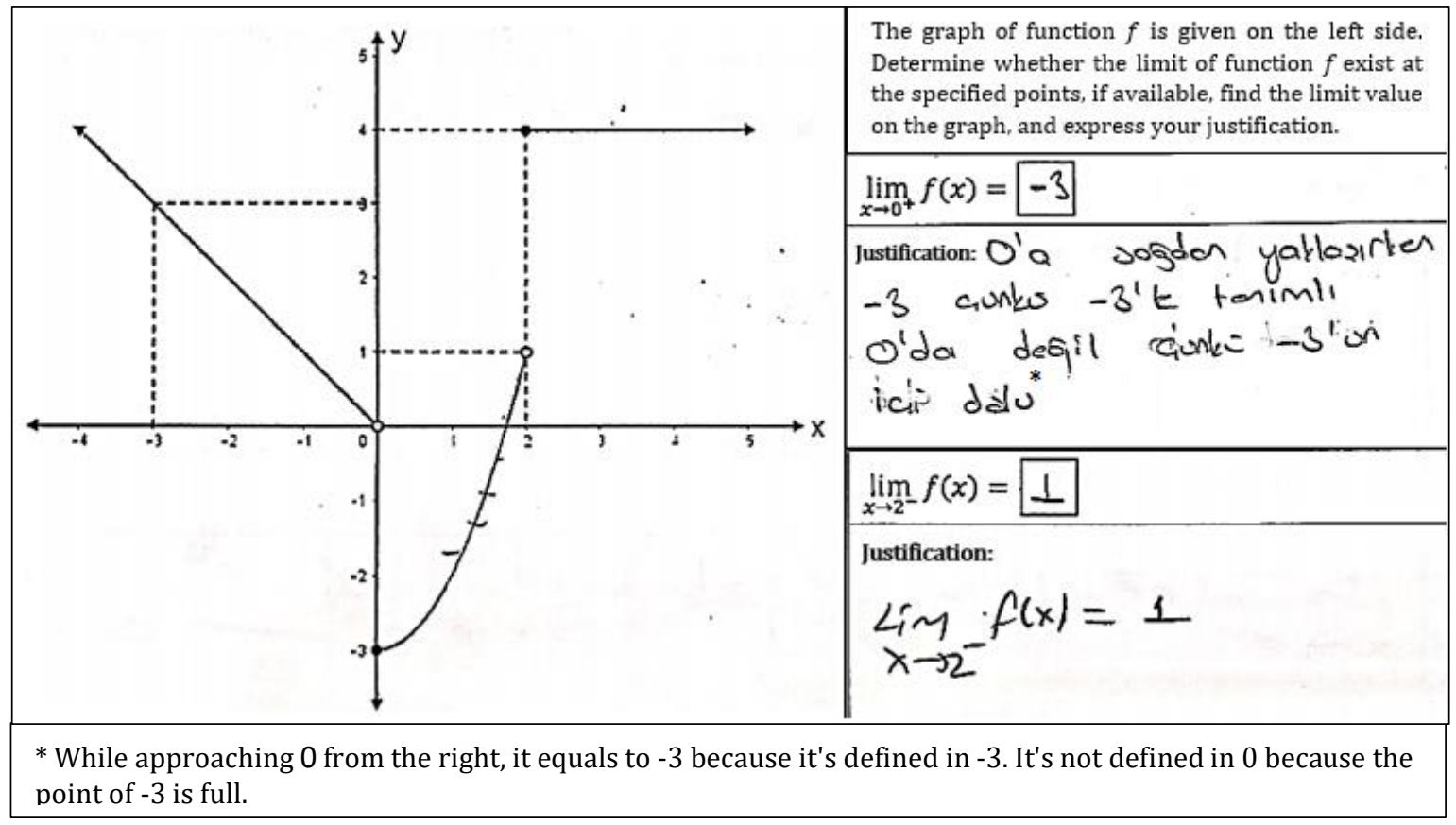

Figure 5. Sample solutions at the GU2 level for Q5a and Q5b

As shown in Figure 5, although the pre-service teacher correctly stated the limit value of the relevant point from the right in Q5a, the justification he provided was not sufficient. The pre-service teacher provided a justification pointing out that the limit value of the function at a point should be defined at that point. This shows that the pre-service teacher made a decision depending on the inclusion of the value at the relevant point in the value set of the function and provided a partial justification. In Q5b, the other pre-service teacher correctly stated the limit of the function from the left at the relevant point but did not provide any justification.

\subsection{Findings Regarding the Pre-Service Science Teachers' Algebraic Understanding Levels Concerning the Concept of Limit}

The answers of the pre-service science teachers to the questions aimed at determining their algebraic understanding levels were analyzed based on the indicators in the algebraic understanding categorical scoring chart. The frequency and percentage distribution obtained from this analysis are presented in Table 5.

Table 5. Frequency and Percentage Distribution of Algebraic Understanding Levels

\begin{tabular}{|c|c|c|c|c|c|c|c|c|c|c|c|c|c|}
\hline \multirow{2}{*}{\multicolumn{2}{|c|}{ Question }} & \multirow{2}{*}{\multicolumn{2}{|c|}{ Q2 }} & \multicolumn{4}{|c|}{ Q6 } & \multirow{2}{*}{\multicolumn{2}{|c|}{ Question }} & \multirow{2}{*}{\multicolumn{2}{|c|}{ Q3 }} & \multirow{2}{*}{\multicolumn{2}{|c|}{ Total }} \\
\hline & & & & \multicolumn{2}{|c|}{ Q6A } & \multicolumn{2}{|c|}{ Q6b } & & & & & & \\
\hline & & f & $\%$ & f & $\%$ & f & $\%$ & Le & & f & $\%$ & f & $\%$ \\
\hline \multirow{4}{*}{ AU0 } & $\mathbf{a}$ & 6 & 7.32 & 4 & 4.88 & 6 & 7.32 & \multirow{4}{*}{ AU0 } & & & & \multirow{4}{*}{132} & \multirow{4}{*}{40.2} \\
\hline & b & 3 & 3.66 & 4 & 4.88 & 3 & 3.66 & & $\mathbf{a}$ & 31 & 37.8 & & \\
\hline & c & 18 & 22 & 1 & 1.22 & 0 & 0 & & & & & & \\
\hline & d & 5 & 6.1 & 5 & 6.1 & 7 & 8.54 & & b & 39 & 47.6 & & \\
\hline \multirow{5}{*}{ AU1 } & $\mathbf{a}$ & 2 & 2.44 & 4 & 4.88 & 3 & 3.66 & \multirow{5}{*}{ AU1 } & & \multirow{5}{*}{4} & \multirow{5}{*}{4.88} & \multirow{5}{*}{78} & \multirow{5}{*}{23.8} \\
\hline & b & 5 & 6.1 & 1 & 1.22 & 3 & 3.66 & & & & & & \\
\hline & c & 0 & 0 & 0 & 0 & 0 & 0 & & & & & & \\
\hline & d & 18 & 22 & 0 & 0 & 0 & 0 & & & & & & \\
\hline & e & 9 & 11 & 13 & 15.9 & 16 & 19.5 & & & & & & \\
\hline
\end{tabular}


Table 5 continued

\begin{tabular}{|c|c|c|c|c|c|c|c|c|c|c|c|c|c|}
\hline \multirow{2}{*}{\multicolumn{2}{|c|}{ Question }} & \multirow{2}{*}{\multicolumn{2}{|c|}{ Q2 }} & \multicolumn{4}{|c|}{ Q6 } & \multirow{2}{*}{\multicolumn{2}{|c|}{ Question }} & \multirow{2}{*}{\multicolumn{2}{|c|}{ Q3 }} & \multirow{2}{*}{\multicolumn{2}{|c|}{ Total }} \\
\hline & & & & \multicolumn{2}{|c|}{ Q6A } & \multicolumn{2}{|c|}{ Q6b } & & & & & & \\
\hline & & f & $\%$ & $\mathbf{f}$ & $\%$ & f & $\%$ & \multicolumn{2}{|c|}{ Level } & f & $\%$ & f & $\%$ \\
\hline \multirow{3}{*}{ AU2 } & $\mathbf{a}$ & 0 & 0 & 0 & 0 & 0 & 0 & \multirow{3}{*}{\multicolumn{2}{|c|}{ AU2 }} & & & & \\
\hline & b & 0 & 0 & 0 & 0 & 0 & 0 & & & 2 & 2.44 & 13 & 3.96 \\
\hline & c & 7 & 8.54 & 0 & 0 & 4 & 4.88 & & & & & & \\
\hline \multirow{3}{*}{ AU3 } & $\mathbf{a}$ & 9 & 11 & 16 & 19.5 & 13 & 15.9 & \multirow{3}{*}{ AU3 } & & & & \multirow{3}{*}{100} & \multirow{3}{*}{30.5} \\
\hline & b & 0 & 0 & 0 & 0 & 0 & 0 & & $\mathbf{a}$ & 0 & 0 & & \\
\hline & c & 0 & 0 & 34 & 41.5 & 27 & 32.9 & & b & 1 & 1.22 & & \\
\hline AU4 & & 0 & 0 & 0 & 0 & 0 & 0 & AU4 & & 5 & 6.1 & 5 & 1.52 \\
\hline
\end{tabular}

As shown in Table 5, 64\% of the pre-service teachers are concentrated at the AU0 and AU1 levels in terms of algebraic understanding. Approximately $32 \%$ of the pre-service teachers are at the AU3 and AU4 levels. This shows that the majority of pre-service teachers have a low level of algebraic understanding of the concept of limit. Approximately $4 \%$ of the pre-service teachers are at the AU2 level, which refers to moderate algebraic understanding. This level has the lowest percentage after AU4 (1.52\%).

The pre-service teachers' concentration at the AU0 level resulted from their answers to Q3 in the open-ended exam. Another question that caused them to be at this level is Q2. The Q3 solutions of two pre-service teachers who misstated the limit value by performing algebraic operations incorrectly are given in Figure 6 .

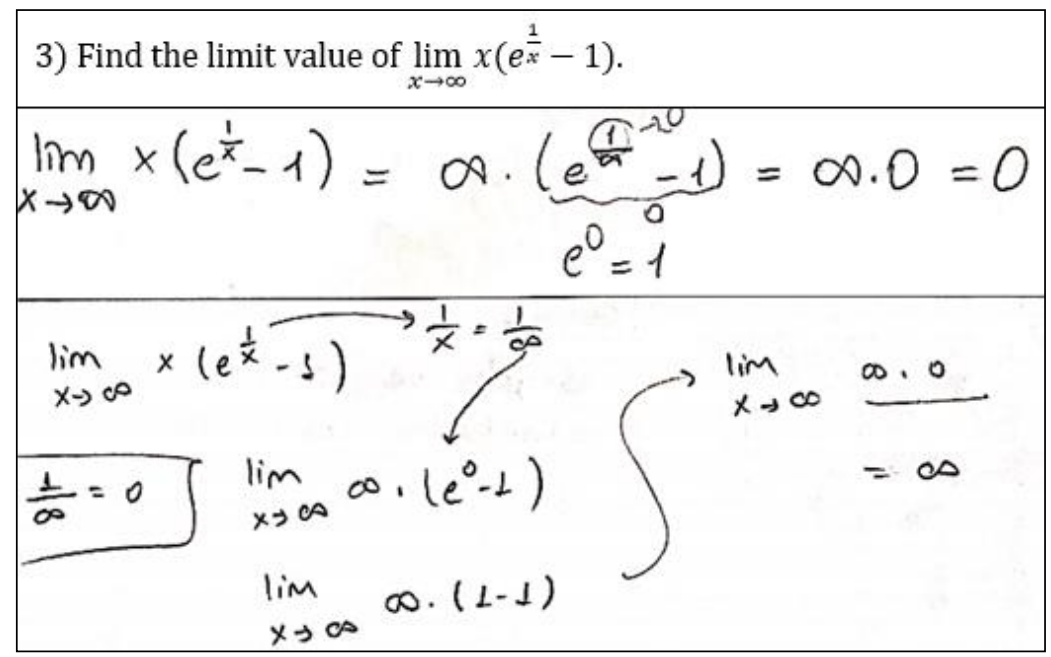

Figure 6. Sample solutions for AU0 level related to Q3

As shown in Figure 6, although both pre-service teachers reached the uncertainty $0 . \infty$ by performing algebraic operations, they could not notice that this expression was a situation of uncertainty. One of the preservice teachers misstated the result of this expression as " 0 " and another pre-service teacher as " $\infty$ ". On the other hand, in this question, it was expected from the pre-service teachers to perform the right algebraic operations to eliminate this uncertainty and find the limit value as " 1 ".

Among the algebraic understanding levels, AU3 has the highest percentage (30.5\%) after the AU0 level. The answers associated with this level mostly came out in question Q6, and these answers had a percentage of $61 \%$ for Q6a and 48.8\% for Q6b. Figure 7 presents the Q6 solutions of two different pre-service teachers who reached the correct limit value by making the right decision for the existence of the limit and performing partly correct algebraic operations. 


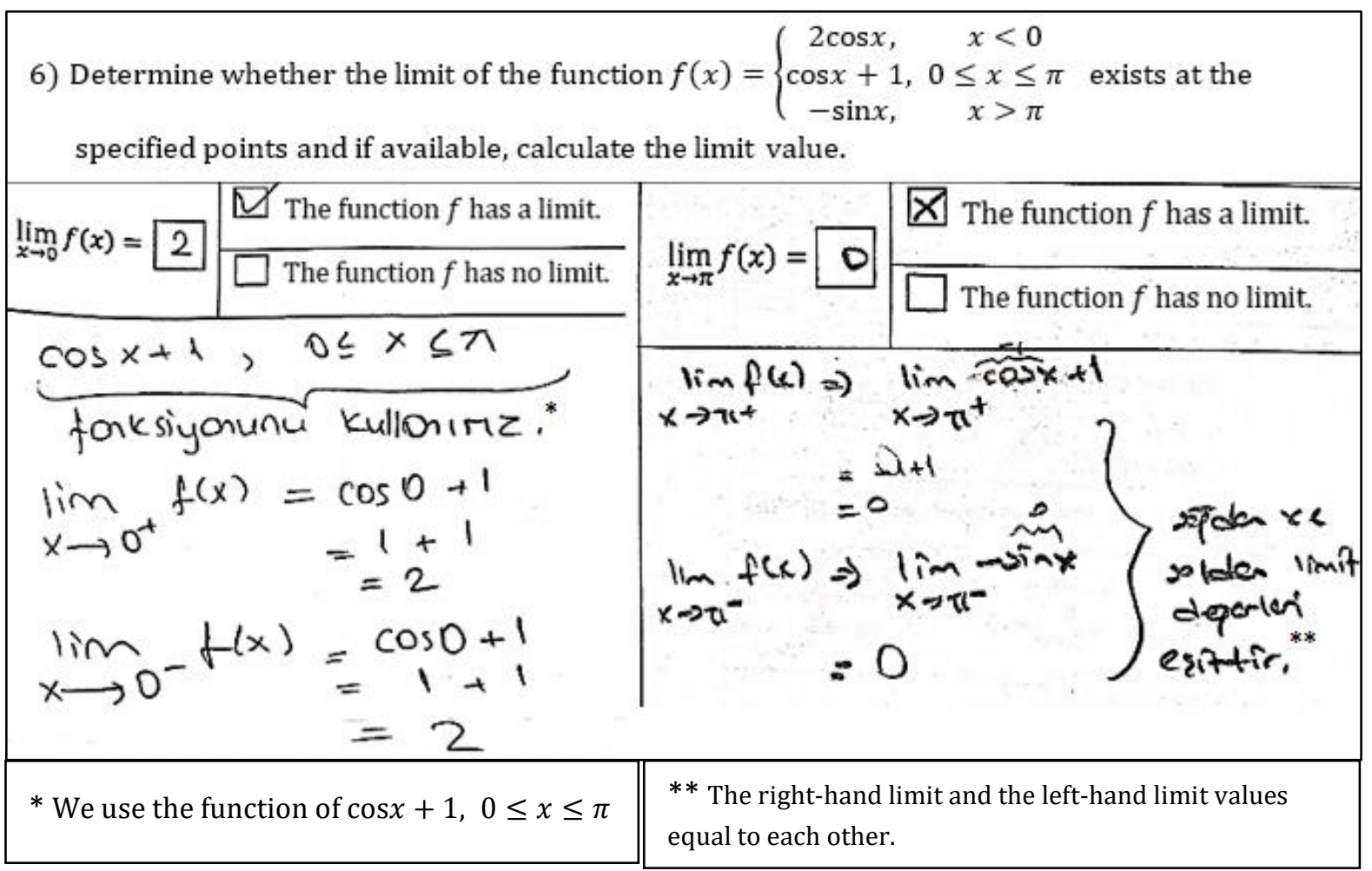

Figure 7. Sample solutions at the AU3 level for Q6a and Q6b

The answers relevant to the AU4 level, which is the highest level of algebraic understanding, appeared only in Q6. Therefore, the number of the pre-service teachers having algebraic understanding at this level is quite small. The understanding level having the lowest percentage after this level is AU2. Figure 8 illustrates the AU2level solution of a pre-service teacher who made the right decision for the existence of the limit but reached a wrong limit value by performing partly correct algebraic operations.

2) Determine whether the limit of the function $f(x)=\frac{\ln |x|}{x}$ exists at $x=0$ and calculate the limit value, if available.

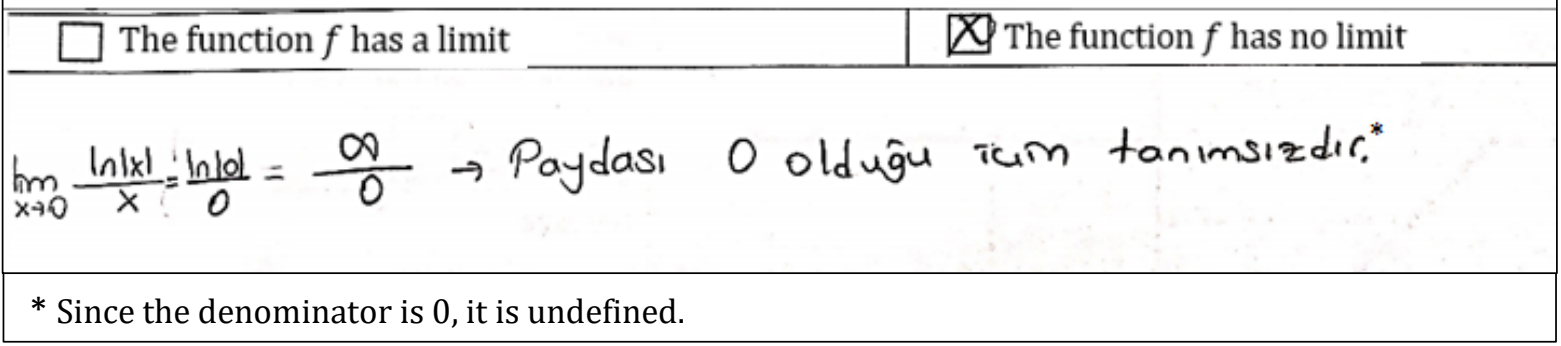

Figure 8. Sample solution at the AU2 level for Q2

As shown in Figure 8, the pre-service teacher carried out algebraic operations without examining the limits of the function from the right and left at the relevant point. In this context, the pre-service teacher performed a partly correct algebraic operation by stating that the result of the expression $\lim _{x \rightarrow 0} \ln |x|$ was " $\infty$ ". After this algebraic operation, he made the right decision for the existence of the limit by defining the expression $\frac{\infty}{0}$ as undefined directly without performing some operation steps in between.

\subsection{Comparison of the Pre-Service Teachers' Graphical and Algebraic Understanding Levels Concerning the Concept of Limit}

The pre-service teachers' graphical and algebraic understanding levels concerning the concept of limit were compared by considering equivalent questions. To this end, the percentages of each pair of questions relevant to understanding levels were determined. In addition, percentages were determined for each level in terms of graphical and algebraic understanding, and comparisons were made. 
Firstly, it was aimed to determine the pre-service teachers' graphical and algebraic understanding levels in each pair of equivalent questions (Q1-Q2, Q4-Q3, and Q5-Q6). Table 6 presents the comparison of graphical and algebraic understanding levels over equivalent questions.

Table 6. Comparison of Understanding Levels over Equivalent Questions

\begin{tabular}{ccccccc}
\hline \multirow{2}{*}{$\begin{array}{c}\text { Graphical - Algebraic } \\
\text { Understanding Levels }\end{array}$} & $\mathbf{G U}$ & $\mathbf{A U}$ & $\mathbf{G U}$ & $\mathbf{A U}$ & $\mathbf{G U}$ & AU \\
\cline { 2 - 8 } & $\mathbf{Q 1}(\boldsymbol{\%})$ & $\mathbf{Q 2}(\boldsymbol{\%})$ & $\mathbf{Q 4}(\boldsymbol{\%})$ & $\mathbf{Q 3}(\boldsymbol{\%})$ & $\mathbf{Q 5}(\boldsymbol{\%})$ & $\mathbf{Q 6}(\boldsymbol{\%})$ \\
\hline Level 0 & 21.95 & 39.02 & 8.54 & 85.37 & 34.15 & 18.29 \\
\hline Level 1 & 30.49 & 41.46 & 27.44 & 4.87 & 10.98 & 24.39 \\
\hline Level 2 & 3.66 & 8.54 & 3.05 & 2.44 & 15.85 & 2.44 \\
\hline Level 3 & 21.95 & 10.98 & 37.8 & 1.22 & 5.48 & 54.88 \\
\hline Level 4 & 21.95 & 0 & 23.17 & 6.1 & 33.54 & 0 \\
\hline
\end{tabular}

As shown in Table 6, in general, the pre-service teachers were able to correctly determine the limit value of the function stated in the equivalent questions over the graph. Therefore, the pre-service teachers are at higher levels in the questions associated with graphical understanding (Q1 and Q4) in the first two pairs of equivalent questions (Q1 and Q2 and Q4 and Q3). However, in Q5 and Q6, approximately 39\% are at higher graphical understanding levels, and about 55\% are at higher algebraic understanding levels. This shows that the pre-service teachers are at higher levels in terms of algebraic understanding in the last pair of equivalent questions. Although the pre-service teachers are at higher algebraic understanding levels (54.88\% at the AU3 level) in this pair of questions, they could not provide an answer at the AU4 level (0\%), which is the highest level.

Graph 1 shows a comparison of the pre-service teachers' levels of understanding the concept of limit in graphical and algebraic terms.

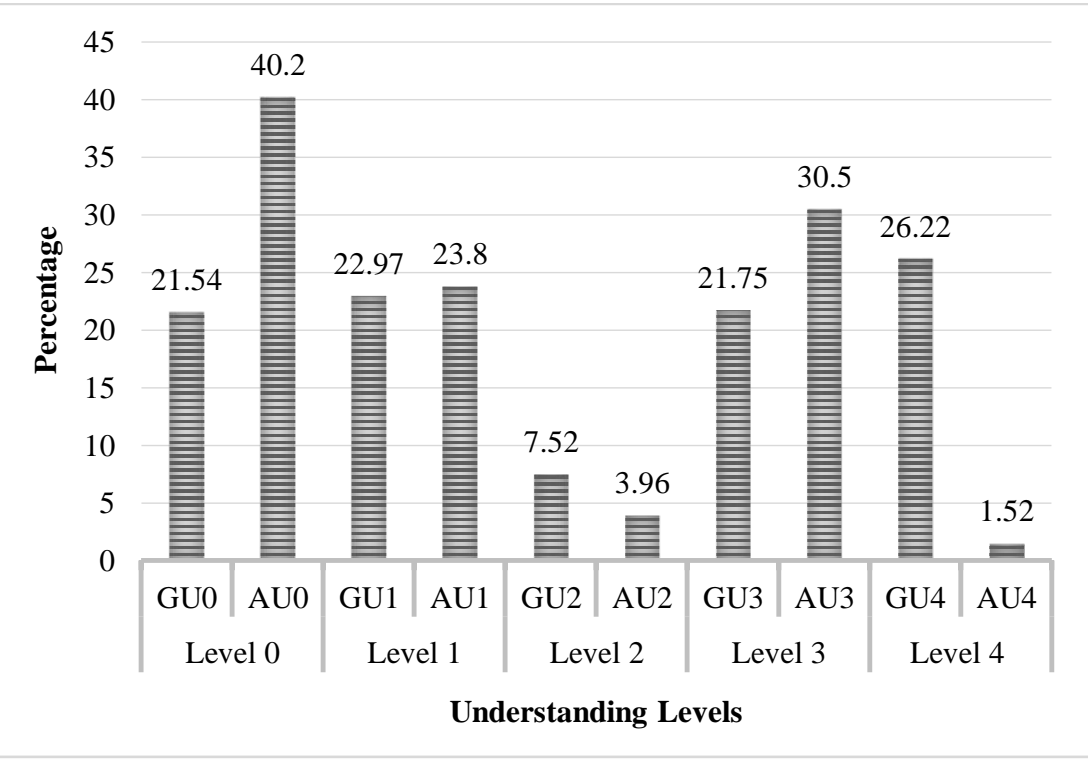

Graph 1. Comparison of the understanding levels in graphical and algebraic terms

As shown in Graph 1, when each level of understanding is examined graphically and algebraically, it is seen that algebraic understanding of the limit is generally higher at lower levels. It is observed that the algebraic understanding rate for the limit is higher than the graphical understanding rate (GU0: 21.54\%; AU0: 40.2\%) at the level 0 , which is considered as the lowest level. This indicates that the pre-service teachers are at a lower level in terms of algebraic understanding. It is seen that graphical understanding has higher rates in higher understanding levels. It is particularly noteworthy that the graphical understanding level of the pre-service teachers has quite a high rate compared to algebraic understanding (GU4: 26.22\%; AU4: 1.52\%) at the fourth level. Therefore, it is apparent that the pre-service teachers' graphical understanding of the limit is more prominent than their algebraic understanding.

\section{Discussion, Conclusion, and Recommendations}

This study aimed to examine pre-service science teachers' graphical and algebraic understanding levels concerning the concept of limit. To this end, an open-ended exam was administered to the pre-service teachers, and their graphical and algebraic understanding levels were determined. Based on the findings, it was concluded 
that the pre-service teachers' graphical understanding of the concept of limit is generally at high level. However, their algebraic understanding was determined to be at low level. This indicates that although the pre-service teachers can easily determine the limit value of a function on the graph, they cannot reach the limit value by correctly performing algebraic operations in general. The fact that the pre-service science teachers frequently encounter situations that require them to make interpretations through graphs in major area courses such as physics, chemistry, and biology may have contributed to their higher level of graphical understanding. Graphs are one of the concrete materials that are frequently used to facilitate learning and increase the permanence of what is learned in science classes (Taşdemir, Demirbaş, \& Bozdoğan, 2005). Taşar, İngeç and Güneş (2002) emphasized the importance of the skills of drawing graphs and understanding in the process of obtaining results from experiments carried out in science classes. They stated that drawing graphs and interpretation are frequently used in experiments performed in laboratory classes, especially in the stages of recording data, data classification, finding the significant relationships between them, and presenting the results. Bowen and Roth (2003), stating that graphs provide concretization by presenting a summary of the relationship between two or more variables, emphasize that that they are a very basic concretization tool for science. The expressions stated by Bowen and Roth (2003) are important with regards to justify to the result "pre-service science teachers' graphical understanding was at a high level" obtained from this study. In addition, the fact that the graph of a function visually provides concrete data about the behavior of that function around the relevant point may have supported the higher level of graphical understanding among the pre-service teachers. As a matter of fact, Arslan and Çelik (2013) pointed out the importance of analyzing tables and graphs in forming a conceptual basis for the behavior of a function around a certain point before moving to the formal definition of the limit. It can be said that the use of the table and graph analysis approach, which is important for the creation of the intuitive definition, in the general mathematics course is one of the reasons that led to the higher level of graphical understanding among the pre-service teachers. The existence of studies indicating that students are more successful in understanding the intuitive definition of the limit (Cottrill et al., 1996; İ. Çetin, 2009) supports this result. The pre-service teachers' high level of graphical understanding means that they were able to determine the limit value from the right and left at the relevant point on the graph and thus make appropriate decisions about the existence of the limit of the function and provide adequate justifications.

It was determined to be more difficult for the pre-service teachers to decide the existence of the limit on a graph if the limit of a function turns out to be infinite around a real number from the right or left. However, they were found to be able to decide the existence of the limit much more easily when the value of the limit of a function around a real number turns out to be again a real number. This may be because the concept of the infinity is not fully imprinted in the minds of students. Özmantar (2013) stated that although the concept of the infinity is included in curricula from pre-school to university level, students have difficulty in making sense of this concept at all levels. Singer and Voica (2003) noted that the intuitive understanding of the infinity by students at primary school level is an obstacle to the construction of the true meaning of this concept. Tsamir and Dreyfus (2002) reported that high school and university students have inconsistent ideas about the concept of the infinity. Therefore, it is possible that the pre-service teachers could not correctly decide the limit value of a function when the limit of the function from the left or right turned out to be infinite because they could not internalize the concept of the infinity. The existence of studies emphasizing the concept of the infinity as an epistemological obstacle to understanding the concept of limit (Elia et al., 2009; Sierpinska, 1987) explains this result.

It was found that the pre-service teachers' graphical understanding was at a higher level in terms of deciding the existence of the limit of a function and finding the limit value on the piecewise function graph. One of the reasons for this may be that the pre-service teachers encountered more piecewise functions and operations performed on these functions in their previous education. Another reason may be that the right and left limit values of functions are generally examined through piecewise function examples at both high school and undergraduate levels. In addition, the fact that the value of the limit turned out to be a finite real number through examination of the limit from one side (only from right or only from left) in the piecewise function question aimed at determining graphical understanding may have caused the pre-service teachers to have higher graphical understanding in that question.

The fact that the limit value turned out to be infinite from one side when examining the limit value in the neighborhood of a certain point in the piecewise function graphs generally posed a problem for the pre-service teachers. However, the fact that the limit value turned out to be a real number in the piecewise function question in the open-ended exam may have also led to a higher level of graphical understanding among the pre-service teachers. There was also a case where the pre-service teachers had difficulty although their graphical understanding was at a high level in the piecewise function question. The pre-service teachers who ignored the fact that the limit does not need to be defined at the point where it is examined attempted to examine the continuity of the function when determining the limit value and thus were mistaken. 
The lowness of the pre-service teachers' algebraic understanding means that they could not perform algebraic operations correctly, could not make the right decision about the existence of the limit, and thus could not reach the correct limit value. The fact that the pre-service science teachers were more prone to reading and interpreting graphs might have caused their algebraic understanding to be found low. Baki and Çekmez (2012) emphasized that algebraic representations should be supported by graphs in teaching the formal definition of the limit to preservice mathematics teachers. Attention should be paid to performing algebraic operations, in addition to the use of graphs, in teaching the intuitive definition of the limit to pre-service science teachers. Similarly, Fernandez (2004) did not give the formal definition of the limit to the pre-service mathematics teachers directly. In that study, the pre-service teachers discussed the formal definition of functions by engaging in both graphical and algebraic examinations over a single example. In this respect, when teaching the limit to pre-service science teachers, learning environments that allow to them to determine the limit value through both graphical and algebraic examinations over the same example may be created. This may help pre-service science teachers to attain conceptual understanding of the limit.

One of the questions where the pre-service teachers had low level of algebraic understanding was the question about uncertainty. Algebraic understanding was also found to be low in the question involving finding the limit value of the rational function including logarithm and absolute value functions. Their failure in performing the required algebraic operations in the uncertainty situation $0 . \infty$ included in the open-ended exam may have resulted from their familiarity with the uncertainty situations $\frac{0}{0}$ and $\frac{\infty}{\infty}$ more. Özmantar and Yeşildere (2013) determined that the students could not perform the necessary operations to eliminate the uncertainty in some uncertainty situations they encountered when taking the limit. In fact, the operations to perform to find the limit in an uncertainty situation are the steps that form the basis of algebraic understanding. The reasons for wide failure in answering the question about the rational function may be the pre-service teachers' imperfect knowledge of the definition of the logarithm and absolute value functions and their less experience in algebraic operations concerning these functions. Bukova (2006) stated that as the type of a function changes, the difficulties experienced by the students in taking the limit increase. In addition, that study found out that the students who did not have experience with different types of functions had problems in the concepts of the limit, continuity, and derivative depending on the type of the function, which supports this result obtained in the present study. On the other hand, the pre-service teachers were able to correctly perform the algebraic operations in the piecewise function question, which was another question associated with algebraic understanding. The reason may be that the two-step examination of the limit from the right and left is similar to the nature of the piecewise function. Another reason may be that in general, examples concerning piecewise functions were preferred in the examination of the limit of the functions from the right and left through algebraic operations, as was the case over graphs.

When the graphical and algebraic understanding of the pre-service teachers was compared over the equivalent questions in the open-ended exam, significant differences were found in terms of understanding levels. The rate of the pre-service teachers who were at higher levels of understanding in the algebraic form of the rational function was quite low compared to that of the pre-service teachers who attained high levels in the graphical form of the same question. A similar situation was observed in the results obtained from the graphical and algebraic forms of the question regarding uncertainty as well. However, the pre-service teachers were able to reach high levels of understanding in the algebraically expressed piecewise function question. They were determined to be able to reach the high algebraic understanding level only with the answers they gave to this question. This study described a current situation by examining the graphical and algebraic understanding of the pre-service science teachers. We think that the results obtained from this study will give an idea to the faculty members about the teaching practices in order to support the graphical and algebraic understanding of preservice science teachers in a teaching on the concept of limit. Future studies may design a learning environment to support pre-service science teachers' algebraic understanding of the concept of limit and focus on how this environment contributes to the improvement of pre-service teachers' algebraic understanding levels. Within the scope of this study, in a sense, "a photograph of the current situation" was taken without any intervention to teaching process. In future studies, through interventions that will promote both understanding levels (e.g. design of learning environments), it can be examined in more depth how pre-service teachers' understanding levels change. 


\section{Fen Bilgisi Öğretmen Adaylarının Limit Kavramına Yönelik Grafiksel ve Cebirsel Anlamalarının İncelenmesi}

\section{Giriş}

Matematik, günlük yaşamımızda karşılaş̧ı̆̆ımız birçok problemi çözmeye yardımcı olan ve yaşamımızı kolaylaştıran bir rol üstlenmektedir (Davis, Hersch ve Marchisotto, 2015). Bununla birlikte nitelikli bir yaşam sürdürebilme yolunda bir meslek edinmenin ön şartlarından biri de belirli düzeyde matematik bilgisine sahip olabilmektir. Bu anlayış; fen bilimlerinin, sosyal bilimlerin ve sağlık bilimlerinin temel düzeyden ileri düzeye kadar matematiğin kullanımını gerektirdiğini göstermektedir. Dolayısıyla gerek ticaret ve mühendislikte gerekse temel bilimlerde matematiksel kavram bilgisi ile işlemleri etkili bir şekilde yürütebilme bilgisinin kullanımı kaçınılmazdır (Travers ve Westbury, 1989). Üniversite eğitiminde birçok fakültede lisans programları ayırt edilmeksizin matematik derslerine yer verilmesi de bu durumu destekler niteliktedir.

Lisans eğitimi sürecinde gerek analiz gerekse genel matematik adı altında dersler verilmekte ve bu derslerde çeşitli matematiksel kavramlar ele alınmaktadır. Küme, bağıntı, fonksiyon, limit, süreklilik, türev ve integral bu temel kavramlar arasındadır. Bu matematiksel kavramlar tıpkı bir zincir halkası gibi birbirine bağlıdır (Dede ve Argün, 2004; Öztürk, 2016). Başka bir ifadeyle herhangi bir kavram daha önceki kavramların oluşturduğu temel üzerine inşa edilerek şekillenmektedir (O'Halloran, 2015). Süreklilik, türev ve integral kavramlarının şekillendirilmesinde de temel teşkil eden önemli kavramlardan biri limittir (Arslan ve Çelik, 2013; Cornu, 2002, N. Çetin, 2009). Çember içerisine yerleştirilen düzgün çokgenin kenar sayısının arttırılmasıyla alan hesabının yapılması (Millı̂ Eğitim Bakanlığı [MEB], 2005), fonksiyonların asimptotlarının belirlenmesi, geometrik serilerin toplamının hesaplanması (Parameswaran, 2007), türev ve integral tanımlarının oluşturulması (Cornu, 2002; Denbel, 2014) gibi birçok durumda limit kavramına başvurulmaktadır. Bu bakımdan limit kavramının tam anlamıyla öğrenilmemesi durumunda analiz ya da genel matematik derslerine yönelik yüzeysel bilgiler edinilmesinin kaçınılmaz olacağı söylenebilir (Arslan ve Çelik, 2013; Özmantar ve Yeşildere, 2013; Lee, 1992).

Analiz ve genel matematiğin neredeyse bütün konularının merkezindeki limit, eğitim fakültelerinin lisans programlarından biri olan fen bilgisi öğretmenliğinde de yer almaktadır. Limit soyut kavramların zihinde yer edinebilmesinde matematik için önemli görülse de fizik, kimya, biyoloji gibi fen bilimlerinin farklı alanlarında da limitin önemi yadsınamaz. Örneğin, fizik alanında bir noktadaki basınç değerinin hesaplanması, biyoloji alanında sürdürülebilir popülasyonun tahmin edilmesi, kimya alanında ise termodinamik dengenin sağlanmas1 limit kavramıyla ilişsili olan durumlardır. Bu bakımdan fen bilimlerinde temel düzeyde de olsa limit kavramına yönelik bir alt yapı oluşturulmasına ihtiyaç vardır. Bir fen bilgisi öğretmeninin fizik, kimya ve biyoloji alanlarının her birine yönelik yeterli düzeyde bilgi ve donanıma sahip olmakla birlikte (Akpınar ve Ergin, 2004; Bardak ve Karamustafaoğlu, 2016) temel düzeyde fonksiyon bilgisine ve fonksiyonun belirli bir nokta civarındaki davranışını betimleyen limit kavramı bilgisine sahip olması gerekmektedir. Bu anlamda fen bilgisi öğretmenliği programında yürütülen genel matematik dersi kapsamında limit kavramı ele alınmaktadır. Bu dersin içeriğinde limit kavramının formal tanımı $(\varepsilon-\delta$ tanımı) verilmeyip sezgisel tanımına yer verilmektedir. Limitin sezgisel tanımı "Bir $f$ fonksiyonu $x_{o}$ noktasının komşuluğundaki tüm $x$ değerleri için tanımlı $\left(x_{o}\right.$ noktasında tanımlı olmak zorunda değil) olsun. $x, x_{o}$ 'a yeterince yaklaştığında $f(x)$ de bir $L$ reel sayısına yaklaşıyorsa $x, x_{o}$ 'a giderken $f(x)$ 'in limiti $L$ olarak ifade edilir ve $\lim _{x \rightarrow x_{o}} f(x)=L$ ile gösterilir." şeklinde ele alınmaktadır (Ertem-Akbaş, 2016).

Matematiksel kavramların anlaşılmasında hiyerarşik bir yapı söz konusudur. Gerek geometri gerekse analiz kavramlarının öğrenciler tarafindan öğrenilmesinde çeşitli anlama düzeyleri mevcuttur. Van Hiele (1957), geometri kavramlarını anlamaya yönelik düzeyler tanımlarken Fless (1988) ile Lee (1992) analiz kavramlarını anlamaya yönelik düzeyler tanımlamıştır. Analiz kavramlarından limiti anlamaya yönelik çeşitli düzeyler belirleyen Lee (1992), limit ile birlikte türevi ele alan Fless'in (1988) anlama düzeylerini temel almıştır. Ancak Lee (1992) sadece limit kavramına odaklanarak anlama düzeylerini tek bir kavram üzerinden daha derinlemesine incelemiştir. Lee (1992) limit kavramına yönelik anlama düzeylerini temel düzey, işlemsel düzey, geçiş düzeyi, üst (rigorous) düzey ve soyut düzey olarak tanımlamıştır. Temel düzey, limitin formal tanımına gerek kalmaksızın bir fonksiyon ya da dizinin limitinin varlığı ya da yokluğunun sayısal değerler verilerek veya grafik üzerinden belirlenebildiği düzeydir. İslemsel düzey, limitin gerektirdiği özellikleri kullanarak bir fonksiyon ya da dizinin limitinin belirlendiği düzeydir. Bu düzeyin doğası gereği formal tanıma başvurmaksızın algoritmik işlemler yürütülür. Geçiş düzeyi, limit kavramının $\varepsilon-\delta$ tanımında yer alan notasyon ve terminolojinin hem sözel hem de grafiksel olarak açıklanabildiği düzeydir. Bu düzey, bazı temel teoremlerin hangi durumlarda kullanılabileceğine karar verme yeterliliği de gerektirmektedir. Üst düzey, ilk üç düzeyin gerektirdiği yeterliliklerin yanı sıra limit ile ilgili önermelerin ispatlarını yapabilmeyi içermektedir. Soyut düzey ise önceki düzeyler ile ilgili yeterliliklere ek olarak limitin matematikteki rolünün öneminin farkında olmayı ve limit tanımını farklı boyutlardaki uzaylara uygulayarak genellemeler yapabilmeyi gerektirmektedir. Bu düzeylerden ilk ikisinde limitin formal tanımını kullanmaksızın daha çok grafiksel olarak ve cebirsel işlemler aracılı̆̆ıyla temel düzeyde bir anlamlandırma söz 
konusudur. Diğer üç düzey ise daha çok matematik alanına yönelik uzmanlaşma sürecinde erişilmesi beklenen düzeylerdir. Elia, Gagatsis, Panaoura, Zachariads ve Zoulinaki (2009) limitin cebirsel ve geometrik gösterimleri birleştiren temel kavramlardan biri olduğunu belirterek öğretimde her iki gösterimi birlikte kullanmanın bu kavramın tam olarak anlaşılmasına katkı sağlayacağına vurgu yapmıştır. Böylece limit kavramının anlaşılmasında grafiksel ve cebirsel anlamının önemine işaret etmişlerdir. Bununla birlikte genel matematik dersinde fen bilgisi öğretmen adaylarının limit kavramını daha çok grafikler ve cebirsel işlemler üzerinden öğrenmesi, adayların grafiksel ve cebirsel anlama düzeylerinin incelenmesini anlamlı kılmaktadır. Mevcut çalışmada limit kavramına yönelik anlama düzeylerinden temel düzey ve işlemsel düzeye odaklanılmıştır. Lee (1992) tarafindan anlama düzeylerine yönelik yapılan tanımlamalar dikkate alınarak temel düzey "grafiksel anlama", işlemsel düzey ise "cebirsel anlama" perspektifinden incelenmiştir.

Alanyazın incelendiğinde limit kavramına yönelik birçok çalışma yapıldığı görülmektedir (Baki ve Çekmez, 2012; Baştürk ve Dönmez, 2011; Biber ve Argün, 2015; Çıldır, 2012; Denbel, 2014; Ertem-Akbaş, 2016; Lee, 1992; İ. Çetin, 2009; Kepçeoğlu ve Yavuz, 2016; N. Çetin, 2009; Parameswaran, 2007; Tall ve Vinner, 1981; Williams, $1991 \mathrm{vb}$.). Bu çalışmalarda genel olarak öğrenme ortamı tasarımının limit kavramının öğrenilmesine etkisi, limitin formal tanımına yönelik öğrenci anlamaları, limit ve süreklilik ile ilgili kavram yanılgılarının incelenmesine odaklanılmıştır. Ayrıca çalışmaların büyük bir kısmı, matematik öğretmeni adayları ile yürütülmüştür. Lee (1992) lise matematik öğretmeni adayları ile yürüttüğü çalışmada adayların limite yönelik anlamalarını pedagojik alan bilgisinin bazı bileşenleri açısından değerlendirmiştir. Baki ve Çekmez (2012) ise ilköğretim matematik öğretmeni adaylarının limitin formal tanımına yönelik anlamalarını incelemiştir. Kepçeoğlu ve Yavuz'un (2017) deneysel çalışmasında GeoGebra yazılımıyla limit ve süreklilik öğretiminin matematik öğretmen adaylarının başarısına etkisini incelemek amaçlanmıştır. Kepçeoğlu ve Yavuz (2017) tarafından yapılan bu çalışma, bir öğrenme ortamının limit kavramının öğrenilmesine etkisinin belirlenmesine yöneliktir. Biber ve Argün (2015), diğer araştırmacılardan farklı olarak matematik öğretmeni adayları tarafindan iki değişkenli fonksiyonlarda limit kavramının nasıl yapılandırıldığı üzerine bir çalışma yürütmüştür. Kavram yanılgısına yönelik yapılan çalışmalar incelendiğinde Baştürk ve Dönmez (2011) matematik öğretmeni adaylarının limit ve süreklilik ile ilgili yanılgıları üzerine incelemeler yaparken Çıldır (2012) fizik öğretmen adaylarının limit ile ilgili kavram yanılgılarına odaklanmıştır. Çıldır'ın (2012) yürüttüğü çalışmada fizik öğretmenliği programında yer alan genel matematik dersinin işlenişine yönelik adaylardan görüşler de alınmıştır. Yapılan araştırmalar dikkate alındığında limit kavramının matematik öğretmeni adayları dışındaki bir çalışma grubuyla gerek sezgisel gerekse cebirsel anlamalarının incelendiği çalışmaların az sayıda olduğu anlaşılmaktadır. Grafiksel ve cebirsel anlamaya yönelik çalışmaların az sayıda olması ve limit kavramı temel alınarak yapılan çalş̧maların çoğunlukla matematik öğretmeni adayları ile yürütülmesi bu alanda bir çalışmaya ihtiyaç olduğuna işaret etmektedir. $\mathrm{Bu}$ bağlamda çalışmanın amacı, fen bilgisi öğretmen adaylarının limit kavramına yönelik grafiksel ve cebirsel anlama düzeylerinin incelenmesidir. Çalışmanın araştırma problemi ise "Fen bilgisi öğretmen adaylarını limit kavramına yönelik grafiksel ve cebirsel anlama düzeyleri nelerdir?” şeklindedir. Bu betimsel çalışma, limit kavramının kullanılmasını gerektiren alan (fizik, kimya ve biyoloji) derslerini öğretmen adaylarının daha iyi anlamalarına zemin oluşturmak amacıyla öğretim üyelerine genel matematik ders içeriğini şekillendirmeleri açısından katkı sağlayabilir.

\section{Yöntem}

Genel matematik dersini almış olan fen bilgisi öğretmen adaylarının limit kavramına yönelik grafiksel ve cebirsel anlama düzeylerinin incelenmesinin amaçlandığı bu araştırma betimsel bir araştırmadır. Betimsel araştırmalar, üzerinde çalışılan olgulara veya olaylara araştırmacılar tarafindan herhangi bir müdahalenin yapılmadığı araştırmalardır (Sönmez ve Alacapınar, 2014). Olgunun ve olayın 'ne' olduğunu bir müdahale yapmaksızın ortaya çıkarma amacıyla yürütülen betimsel araştırmalar, mevcut durumun değişimini veya gelişimini sağlayacak herhangi bir girişim niteliği taşımamaktır. Limit kavramı fen bilgisi öğretmenliği programında genel matematik dersi kapsamında ele alınan kavramlardan biridir. Bu çalışmada öğretmen adaylarının eğitim-öğretim dönemi sonunda limit kavramına yönelik anlama düzeyleri incelenmiştir. Dersler haftalık program dahilinde doğal akışında yürütülmüştür. Dolayısıyla anlama düzeylerini incelemek üzere araştırmacılar tarafindan öğretmen adaylarına herhangi bir öğretimsel müdahale yapılmamıştır. Mevcut olgu, adayların grafiksel ve cebirsel öğrenme düzeyleridir. Bu olguyu belirlemek üzere adaylara açık uçlu bir sınav uygulanmış ve bu sınava verilen yanıtlar dikkate alınarak anlama düzeyleri belirlenmiştir. $\mathrm{Bu}$ doğrultuda öğretmen adaylarının limit kavramına yönelik grafiksel ve cebirsel anlamaları betimsel bir perspektiften bütüncül olarak yansitılmaya çalışılmıştır.

\subsection{Katılımcilar}

Araştırmanın katılımcıları, bir devlet üniversitesinde fen bilgisi öğretmenliği programının birinci sınıfında öğrenim gören toplam 82 öğretmen adayıdır. Bu adaylar, genel matematik 1 dersi alan ve iki farklı şubede öğrenim gören öğrencilerin tamamıdır. Katılımcıların belirlenmesinde olasılıksız örnekleme türlerinden amaçlı örnekleme yöntemi benimsenmiştir. Amaçlı örnekleme, keşfetmek ve anlamak istenilen bir olaya ya da olguya yönelik birçok şeyin öğrenilebileceği bir örneklem seçiminin zorunlu olduğu varsayımına dayanır (Merriam, 
2015). Araştırma grubunun fen bilgisi öğretmen adayları olarak belirlenmesinin sebebi, fen bilgisi programında yürütülen genel matematik dersinde araştırmanın amacıyla ilişkili olarak limit kavramının daha çok grafiksel ve cebirsel anlamalar bağlamında temel düzeyde işlenmesidir.

\subsection{Veri Toplama Aracı}

Limit kavramına yönelik grafiksel ve cebirsel anlamaları belirlemeye yönelik toplam 6 sorudan oluşan açık uçlu bir sınav kullanılmıştır. Sınavda yer alan soruların grafiksel ve cebirsel olarak sınıflandırılması ve sorular ile ilgili açıklamalar Tablo 1'de sunulmuştur.

Tablo 1. Soruların İçeriğine Yönelik Açıklamalar

\begin{tabular}{|c|c|c|c|}
\hline Anlama & Sorular & & Açıklamalar \\
\hline \multirow{6}{*}{ Grafiksel } & \multirow{2}{*}{1} & $\mathbf{a}$ & $\begin{array}{l}\text { Fonksiyonun limit değerinin grafik üzerinden sonsuz olarak belirlenmesinin } \\
\text { reel sayılar kümesi üzerinde limitin mevcut olmadığının bir göstergesi } \\
\text { olduğuna karar verilmesi ve gerekçe sunulmasını gerektirmektedir. }\end{array}$ \\
\hline & & b & $\begin{array}{l}\text { Grafik üzerinde sağdan ve soldan limit değerlerinin birbirine eşit olduğunun } \\
\text { belirlenmesini, fonksiyonun limitinin varlığını karar verilmesini ve gerekçe } \\
\text { sunulmasını gerektirmektedir. }\end{array}$ \\
\hline & \multirow{2}{*}{4} & $\mathbf{a}$ & $\begin{array}{l}\text { Grafik üzerinde fonksiyonun limit değerinin bir taraftan sonsuz olarak } \\
\text { belirlenmesinin limitin mevcut olmadığının bir göstergesi olduğuna karar } \\
\text { verilmesi ve gerekçe sunulmasını gerektirmektedir. }\end{array}$ \\
\hline & & b & $\begin{array}{l}\text { Grafik üzerinde sağdan ve soldan limit değerlerinin birbirine eşit olduğunun } \\
\text { belirlenmesini, fonksiyonun limitinin varlığına karar verilmesini ve gerekçe } \\
\text { sunulmasını gerektirmektedir. }\end{array}$ \\
\hline & \multirow{2}{*}{5} & $\mathbf{a}$ & $\begin{array}{l}\text { Belirli bir noktaya sağdan yaklaşırken parçalı fonksiyon grafiğinin ilgili } \\
\text { parçasını belirlemeyi, bu parça üzerinde inceleme yaparak limit değerine karar } \\
\text { vermeyi ve gerekçe sunmayı gerektirmektedir. }\end{array}$ \\
\hline & & b & $\begin{array}{l}\text { Belirli bir noktaya soldan yaklaşırken parçalı fonksiyon grafiğinin ilgili } \\
\text { parçasını belirlemeyi, limit değerinin fonksiyonun tanımlı olmadığı noktadaki } \\
\text { değere eşit olabileceğine karar vermeyi ve gerekçe sunmayı gerektirmektedir. }\end{array}$ \\
\hline \multirow{4}{*}{ Cebirsel } & \multicolumn{2}{|l|}{2} & $\begin{array}{l}\text { Verilen fonksiyonun limitinin mevcut olup olmadığına tanım kümesini dikkate } \\
\text { alarak ilgili noktanın komşuluklarında cebirsel işlemler yaparak karar vermeyi } \\
\text { gerektirmektir. }\end{array}$ \\
\hline & \multicolumn{2}{|l|}{3} & $\begin{array}{l}\text { Verilen fonksiyonun limit değerini, belirsizlik türünü tespit ederek bu } \\
\text { belirsizliği giderebilecek cebirsel işlemler aracılığıyla bulmayı } \\
\text { gerektirmektedir. }\end{array}$ \\
\hline & \multirow{2}{*}{6} & $\mathbf{a}$ & \multirow{2}{*}{$\begin{array}{l}\text { Verilen parçalı fonksiyonun limitinin ilgili cebirsel ifadeler üzerinde işlemler } \\
\text { yapılarak belirli bir noktada mevcut olup olmadığının belirlenmesini } \\
\text { gerektirmektedir. }\end{array}$} \\
\hline & & b & \\
\hline
\end{tabular}

Çalışmada kullanılan açık uçlu soruların bir kısmı, aynı sorunun grafiksel ya da cebirsel formudur. Bu doğrultuda grafiksel anlamayı belirlemeye yönelik olan birinci ve dördüncü soru, sırasıyla ikinci ve üçüncü soruda cebirsel anlamayı belirlemeye yönelik forma dönüştürülmüştür. Soruların bu şekilde belirlenmesinin temel nedeni, öğretmen adaylarının grafiksel ve cebirsel anlamalarının karşılaştırılmasına kolaylık sağlayacağının düşünülmesidir. Belirtilen dönüşümü gösteren örnek bir soru çifti Şekil 1'de verilmiştir.

Veri toplama aracı olarak kullanılan açık uçlu sınavın geliştirilmesinde üç husus dikkate alınmıştır. Bunlardan ilki, sınavda yer alan soruların limit kavramına ilişkin içeriği tam anlamıyla kapsamasıdır. İkincisi, soruların limit kavramına ilişkin durumlara (ör., limitin varlığı, sağdan ve soldan limit bulma vb.) yönelik gerekçeler sunulmasına olanak sağlamasıdır. Üçüncüsü, soruların grafiksel ve cebirsel anlama bakımından karşılaştırma yapılmasına imkân tanımasıdır. Birinci ve ikinci hususlar gerçekleştirilirken limit kavramına ilişkin kavram yanılgıları da göz önünde bulundurulmuştur. Üçüncü husus ise grafiksel anlamayı belirleme amaçlı kullanılan soruların cebirsel forma dönüştürülmüş hallerinin cebirsel anlamayı belirlemede kullanılmasını açıklar niteliktedir. Bu durumlar dikkate alınarak öncelikle her bir yazar soru önerilerinde bulunmuştur. Ardından sorular üzerinde incelemeler yaparak kapsam geçerliliğini sağlayacak şekilde taslak hali oluşturulmuştur ve bir uzman tarafından soruların taslak hali incelenmiştir. Uzman görüşlerinin alınmasıyla sorular üzerinde düzenlemeler yapılarak bahsedilen süreç tekrarlanmış ve soruların son hali oluşturularak açık uçlu sınava uygulamaya hazır hale getirilmiştir. 


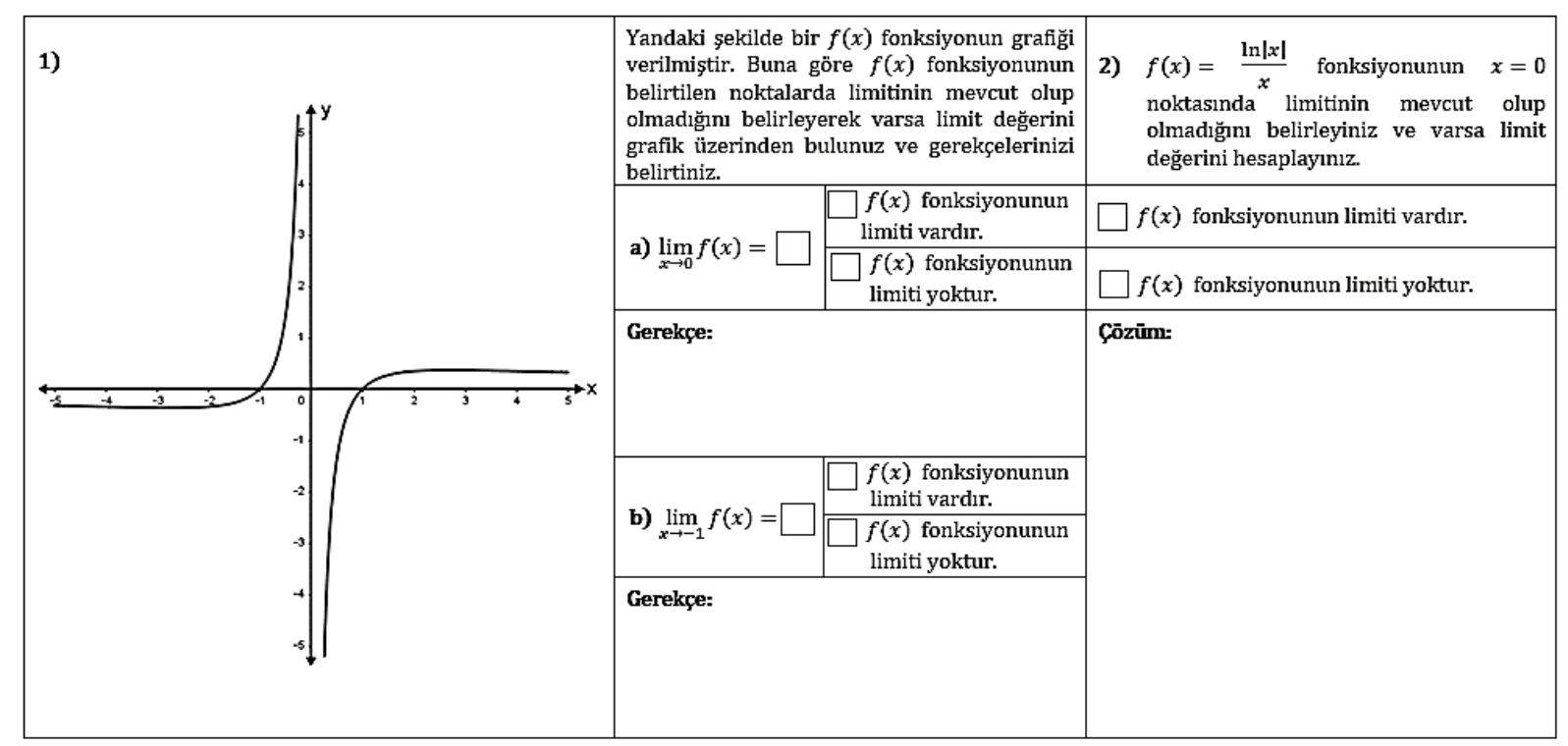

Şekil 1. Grafiksel ve cebirsel anlamayı belirlemeye yönelik eş değer sorular

Veri toplama aracının uygulanması sürecinde ortaya çıkabilecek aksaklıkları görmek ve bu aracın geçerlik ve güvenirliğini test etmek, verilerin analiz edilmesinde nasıl bir yol izleneceğine karar vermek amacıyla pilot çalı̧̧ması yapılmıştır. Pilot çalışması, matematik öğretmenliği programında öğrenim gören dördüncü sınıf öğrencilerine uygulanmıştır. Bu uygulamanın sonucunda parçalı fonksiyonlarda grafiksel ve cebirsel anlamayı belirlemek için farklı soruların kullanılmasının uygun olacağına karar verilmiştir. Bunun sebebi, parçalı fonksiyonun grafiği ile bu fonksiyonun cebirsel ifadesinin iki ayrı soruda verilmesi durumunda bunların öğrenciler tarafindan aynı sorunun iki farklı formu olduğunun doğrudan fark edebilmesidir. Bu doğrultuda son iki soruda belirtilen fonksiyonlar iki farklı parçalı fonksiyon olarak düzenlenmiş̧ir. Bu soruların eş değer olmasını sağlayan temel unsur parçalı fonksiyondur. Bununla birlikte cebirsel anlamaya yönelik son soruda (S6) çözümle birlikte gerekçesinin de istenmesinin gerekli olmadığına karar verilmiştir. Böyle bir kararın alınmasının sebebi, sunulması beklenen gerekçenin çözüm adımlarındaki cebirsel işlemlerle ifade edilmesidir. Bunun sonucunda veri toplama aracı asıl uygulama için uygulanabilir hale getirilmiştir. Ayrıca pilot çalışma ile verilerin analizi için geliştirilen kategorik puanlama cetvellerinde literatür desteğinin yanı sıra ortaya çıkabilecek durumların ihmal edilmesinin önüne geçilmiştir. Bununla birlikte pilot çalışma veri toplama aracının uygulama süresinin belirlemesinde de araştırmaya yön vermiştir.

\subsection{Verilerin Analizi}

Araştırmanın amacı doğrultusunda uygulanan sınavdan elde edilen veriler, grafiksel ve cebirsel anlama kategorik puanlama cetvelleri aracılı̆̆ıyla analiz edilmiş̧ir. Araştırmacılar tarafindan geliştirilen bu kategorik puanlama cetvelleri, öğretmen adaylarının limit kavramı ile ilgili grafiksel ve cebirsel anlama düzeylerini belirlemeye yönelik göstergeler içermektedir. Göstergeler belirlenirken pilot çalı̧̧a sonucunda elde edilen öğrenci yanıtlarına ek olarak alanyazın da (Lee, 1992) dikkate alınmıştır. Bunun sonucunda limit kavramının grafiksel ve cebirsel anlamaya yönelik temel göstergelerine karar verilmiştir. $\mathrm{Bu}$ temel göstergeler "limit varlığına karar verme", "limit değerini ifade etme", "gerekçe sunma" ve "cebirsel işlemler yürütme" dir. Grafiksel ve cebirsel anlama düzeyi ile ilgili göstergeler genel olarak benzer bileşenler etrafinda şekillendirilmesine karşın bu anlamaların doğasının farklı olması, iki ayrı kategorik puanlama cetvelinin geliştirilmesine yol açmıştır. Buna bağlı olarak "gerekçe sunma" grafiksel anlama düzeyinin doğasına uygun göstergelerden biri iken "cebirsel işlem yürütme" cebirsel anlama düzeyinin doğasına uygun göstergelerden biridir. Puanlama cetvellerindeki göstergelere son halinin verilmesi, pilot çalışma ile elde edilen öğrenci yanıtlarındaki bütün olası durumları kapsayacak şekilde yeni göstergelerin eklenmesiyle gerçekleştirilmiştir. Puanlama cetvellerinde belirtilen anlama düzeyleri, temel düzey perspektifinden incelenen grafiksel anlamanın ve işlemsel düzey perspektifinden incelenen cebirsel anlamanın alt kategori düzeyleridir. Grafiksel anlamanın alt kategori düzeyleri (GA0, GA1, GA2, GA3, GA4) ve cebirsel anlamanın alt kategori düzeyleri (CA0, CA1, CA2, CA3, CA4) açık uçlu sınavda yer alan sorulara adaylar tarafindan verilebilecek bütün olası yanıtlar dikkate alınarak belirlenmiştir. Adaylar tarafindan verilen yanıtlar puanlama cetveli dikkate alınarak sıfır (0) puandan dört (4) puana kadar puanlandırılmıştır. Örneğin, grafiksel anlama düzeyini belirlemeye yönelik sorulan S1 sorusunda limitin varlığına "doğru" karar veren, limit değerini "yanlış" ifade eden ve "kısmen" gerekçe sunan bir öğretmen adayı GA2 düzeyinde yer aldığından bu soru için "2" puan almıştır. Anlama düzeyleri ayrı ayrı incelenirken düzeylere yönelik yalnızca frekans ve yüzde dağılımı belirtilmiştir. Grafiksel ve cebirsel anlama 
düzeylerinin karşılaştırılması sürecinde ise adayların toplam puanları dikkate alınmıştır. Veri analizi için kullanılan “Grafiksel Anlama Kategorik Puanlama Cetveli” Tablo 2'de verilmiştir.

Tablo 2. Grafiksel Anlama Kategorik Puanlama Cetveli

\begin{tabular}{|c|c|c|c|c|c|c|c|c|c|}
\hline \multicolumn{3}{|c|}{ Soru } & \multicolumn{3}{|c|}{ S1 ve $S 4$} & \multicolumn{2}{|c|}{ Soru } & \multicolumn{2}{|c|}{ S5 } \\
\hline \multirow[b]{2}{*}{ Kategori } & \multicolumn{2}{|c|}{ Gösterge } & \multirow{2}{*}{$\begin{array}{c}\text { Limit } \\
\text { varlığına } \\
\text { karar } \\
\text { verme }\end{array}$} & \multirow{2}{*}{$\begin{array}{c}\text { Limit } \\
\text { değerini } \\
\text { ifade } \\
\text { etme }\end{array}$} & \multirow[b]{2}{*}{$\begin{array}{c}\text { Gerekçe } \\
\text { sunma }\end{array}$} & Göste & & Limit & \\
\hline & \multicolumn{2}{|c|}{ Düzey } & & & & \multicolumn{2}{|c|}{ Düzey } & $\begin{array}{l}\text { degerini } \\
\text { ifade } \\
\text { etme }\end{array}$ & $\begin{array}{l}\text { Gerekçe } \\
\text { sunma }\end{array}$ \\
\hline \multirow{10}{*}{ 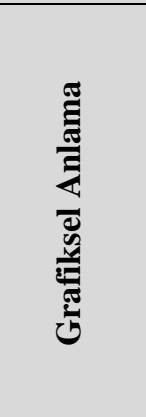 } & \multirow{2}{*}{ GA0 } & $\mathbf{a}$ & Yanit yok & Yanit yok & Yanit yok & \multirow{2}{*}{ GA0 } & $\mathbf{a}$ & Yanit yok & Yanit yok \\
\hline & & b & Yanlış & Yanliş & Yanlış/Hayır & & b & Yanlış & Yanlış/Hayır \\
\hline & \multirow{4}{*}{ GA1 } & $\mathbf{a}$ & Doğru & Yanlış & Yanlış/Hayır & \multirow{4}{*}{\multicolumn{2}{|c|}{ GA1 }} & \multirow{4}{*}{ Yanlış } & \multirow{4}{*}{ Kismen } \\
\hline & & b & Yanlış & Doğru & Yanlış/Hayır & & & & \\
\hline & & c & Doğru & Doğru & Yanlış/Hayır & & & & \\
\hline & & d & Yanlış & Yanlış & Kismen & & & & \\
\hline & \multirow{2}{*}{ GA2 } & $\mathbf{a}$ & Doğru & Yanlış & Kismen & \multirow{2}{*}{\multicolumn{2}{|c|}{ GA2 }} & \multirow{2}{*}{ Doğru } & \multirow{2}{*}{ Yanlış/Hayır } \\
\hline & & b & Yanlış & Doğru & Kismen & & & & \\
\hline & \multicolumn{2}{|l|}{ GA3 } & Doğru & Doğru & Kismen & \multicolumn{2}{|l|}{ GA3 } & Doğru & Kismen \\
\hline & \multicolumn{2}{|l|}{ GA4 } & Doğru & Doğru & Yeterli & \multicolumn{2}{|l|}{ GA4 } & Doğru & Yeterli \\
\hline
\end{tabular}

Veri analizi için kullanılan “Cebirsel Anlama Kategorik Puanlama Cetveli” ise Tablo 3’te verilmiştir.

Tablo 3. Cebirsel Anlama Kategorik Puanlama Cetveli

\begin{tabular}{|c|c|c|c|c|c|c|c|c|c|}
\hline \multicolumn{3}{|c|}{ Soru } & \multicolumn{3}{|c|}{ S2 ve S6 } & \multicolumn{2}{|c|}{ Soru } & \multicolumn{2}{|c|}{ S3 } \\
\hline \multirow{2}{*}{ Kategori } & \multirow{2}{*}{\multicolumn{2}{|c|}{$\begin{array}{c}\text { Gösterge } \\
\text { Düzey }\end{array}$}} & \multirow{2}{*}{$\begin{array}{c}\text { Limit } \\
\text { varlığına } \\
\text { karar } \\
\text { verme }\end{array}$} & \multirow{2}{*}{$\begin{array}{c}\text { Limit } \\
\text { değerini } \\
\text { ifade } \\
\text { etme } \\
\end{array}$} & \multirow{2}{*}{$\begin{array}{l}\text { Cebirsel } \\
\text { işlem } \\
\text { yürütme }\end{array}$} & \multirow{2}{*}{\multicolumn{2}{|c|}{$\begin{array}{c}\text { Gösterge } \\
\text { Düzey }\end{array}$}} & \multirow{2}{*}{$\begin{array}{c}\text { Limit } \\
\text { değerini } \\
\text { ifade etme }\end{array}$} & \multirow{2}{*}{$\begin{array}{l}\text { Cebirsel } \\
\text { işlem } \\
\text { yürütme }\end{array}$} \\
\hline & & & & & & & & & \\
\hline \multirow{16}{*}{ 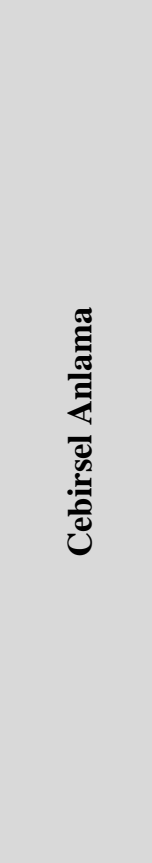 } & \multirow{4}{*}{ CAO } & $\mathbf{a}$ & Yanit yok & Yanit yok & Yanit yok & \multirow{4}{*}{ CAO } & - & \multirow{2}{*}{ Yanit yok } & \multirow{2}{*}{ Yanit yok } \\
\hline & & b & Yanlış & Yanlış & Hayır & & $a$ & & \\
\hline & & c & Yanlış & Yanlış & Yanlış & & \multirow{2}{*}{ b } & \multirow{2}{*}{ Yanlış/Hayır } & \multirow{2}{*}{ Yanlış } \\
\hline & & d & Doğru & Yanlış & Hayır & & & & \\
\hline & \multirow{5}{*}{ CA1 } & $\mathbf{a}$ & Doğru & Doğru & Hayır & \multirow{5}{*}{ CA1 } & & \multirow{5}{*}{ Doğru } & \multirow{5}{*}{ Yanlış } \\
\hline & & b & Doğru & Yanlış & Yanlış & & & & \\
\hline & & c & Yanlış & Doğru & Yanlış & & & & \\
\hline & & d & Doğru & Doğru & Yanlış & & & & \\
\hline & & $\mathbf{e}$ & Yanlış & Yanlış & Kismen & & & & \\
\hline & \multirow{3}{*}{ CA2 } & $\mathbf{a}$ & Yanlış & Yanlış & Doğru & \multirow{3}{*}{ CA2 } & & \multirow{3}{*}{ Yanlış/Hayır } & \multirow{3}{*}{ Kismen } \\
\hline & & b & Yanlış & Doğru & Kismen & & & & \\
\hline & & c & Doğru & Yanlış & Kismen & & & & \\
\hline & \multirow{3}{*}{ CA3 } & $\mathbf{a}$ & Doğru & Doğru & Kismen & \multirow{3}{*}{ CA3 } & ? & \multirow{2}{*}{ Doğru } & \multirow{2}{*}{ Kismen } \\
\hline & & b & Yanlış & Doğru & Doğru & & & & \\
\hline & & c & Doğru & Yanlış & Doğru & & b & Yanlış & Doğru \\
\hline & \multicolumn{2}{|l|}{ CA4 } & Doğru & Doğru & Doğru & \multicolumn{2}{|l|}{ CA4 } & Doğru & Doğru \\
\hline
\end{tabular}

Verilerin kategorik puanlama cetvellerine göre analiz edilmesi sonucunda her bir anlama düzeyinin göstergelerine yönelik frekans ve yüzdeler belirlenmiştir. Bu frekans ve yüzdeler üzerinden öğretmen adaylarının grafiksel ve cebirsel anlama düzeylerine yönelik karşılaştırmalar yapılmıştır.

\subsection{Geçerlik ve Güvenirlik Çalışmaları}

Veri toplama aracı, kategorik puanlama cetveli ve verilerin analizi olmak üzere üç duruma ilişkin geçerlik ve güvenirlik çalışmaları gerçekleştirilmiştir. Veri toplama aracına ilişkin geçerlik ve güvenirlik çalışması olarak açık uçlu sınavının içeriğinde limitin formal tanımı dışında sezgisel tanımı, sağdan ve soldan limit, sonsuz limitler, limit ile ilgili cebirsel işlemler ve teoremler şeklinde limit kavramına ilişkin bütün kapsamı içerecek şekilde sorulara yer verilmiştir. Bununla birlikte matematik eğitimcisi olan bir uzmanın görüşüne başvurularak 
soruların limit kavramına yönelik grafiksel ve cebirsel anlamayı belirlemeye uygun olduğu tespit edilmiştir. Uzman görüşleri birkaç kez alınmakla birlikte tekrarlayan bir süreç şeklinde gerçekleştirilmiştir. Kategorik puanlama cetvellerinin geçerlik ve güvenirlik çalışması kapsamında literatür destekli olarak oluşturulmalarının sonrasında uzman görüşlerine başvurulmuştur. Uzman görüşleri doğrultusunda göstergeleri metin şekilde ifade etmek yerine daha kolay fark edilmesini sağlayabilecek bir yapıya dönüştürülmüştür. Tercih edilen bu yapı, veri analizinin de daha kolay yapılmasına olanak sağlamıștır. Puanlama cetvellerinin son halinin oluşturulması noktasında ön bir veri analizi yapılarak olası göstergelerin gözden kaçırılmasının önüne geçilmiştir. Verilerin analizinde ise kodlama güvenirliğini sağlamak için araştırmacılar verileri bağımsız olarak kodlamıştır. Araştırmacıların kodlamaları arasında \%80 oranında bir uyum olduğu belirlenmiştir. Araştırmacılar, kodlamaları arasındaki uyumsuzluklar üzerine tartışmalar gerçekleştirerek gerekli düzenlemeleri yapmıştır.

\subsection{Süreç}

Fen bilgisi öğretmen adaylarının limit kavramına yönelik anlamalarını grafiksel ve cebirsel açıdan incelemeyi amaçlayan bu çalışma, 2017-2018 eğitim ve öğretim yılının güz dönemi genel matematik 1 dersinde kavram ile ilgili gerekli alt yapının oluşturulması sonrasında gerçekleştirilmiştir. Genel matematik 1 dersi, matematik eğitimcisi olan yazarlardan biri tarafından yürütülmüştür. Ders sürecinde limit kavramı öğretilirken hem grafik hem de cebirsel işlemler üzerinden kavramın anlamı vurgulanmıştır. Bu bakımdan öğretmen adaylarının grafiksel ve cebirsel anlamalarını dengeli olarak destekleyecek bir öğretim amaçlanmış ve bu ders belirtilen amaca hizmet edecek şekilde planlanarak yürütülmüştür. Bu ders kapsamı, limit kavramının öğretimi amacıyla üç hususa bağlı olarak şekillendirilmiştir. Birincisi, kavramın tanımının özümsenmesi için bir fonksiyonun belirli bir noktanın komşuluğunda değerlerinin nasıl değiştiğine ilişkin bir süreç yaşatmaktadır. İkincisi, her bir fonksiyonunun limitini grafikleri üzerinden araştırmak ya da teyit etmektir. Üçüncü ise bir fonksiyonun limit değerini bulmak için ne tür cebirsel işlemler gerçekleştirilebileceği üzerine tartışmak ve bu işlemleri gerçekleştirmektir. Öğretim döneminin sonunda öğretmen adaylarının limit kavramına yönelik anlamaları açık uçlu bir sınav aracılığıyla belirlenmiştir. Sınavın uygulanması yaklaşık 45 dakika sürmüştür ve adayların sorulara yönelik yanıtları bireysel olarak alınmıştır.

\section{Bulgular}

Fen bilgisi öğretmen adaylarının limit kavramına yönelik grafiksel ve cebirsel anlama düzeyleri ile bu iki düzeyin karşılaştırılması bu bölümde üç alt başlık halinde sunulmuştur.

\section{1.Öğretmen Adaylarının Limit Kavramına Yönelik Grafiksel Anlama Düzeyleri ile İlgili Bulgular}

Çalışmada fen bilgisi öğretmen adaylarının grafiksel anlama düzeylerini belirlemeye yönelik sorulara verdiği yanıtlar, grafiksel anlama kategorik puanlama cetvelinde yer alan göstergelere göre analiz edilmiştir. Bu analiz sonucunda elde edilen frekans ve yüzde dağılımı Tablo 4'te sunulmuştur.

Tablo 4. Grafiksel Anlama Düzeyleri ile İlgili Frekans ve Yüzde Dağılımı

\begin{tabular}{|c|c|c|c|c|c|c|c|c|c|c|c|c|c|c|c|c|c|}
\hline \multirow{3}{*}{\multicolumn{2}{|c|}{$\begin{array}{l}\text { Soru } \\
\text { Düzey } \\
\end{array}$}} & \multicolumn{4}{|c|}{ S1 } & \multicolumn{4}{|c|}{ S4 } & \multirow{2}{*}{\multicolumn{2}{|c|}{ Soru }} & \multicolumn{4}{|c|}{ S5 } & \multirow{2}{*}{\multicolumn{2}{|c|}{ Toplam }} \\
\hline & & \multicolumn{2}{|c|}{ S1a } & \multicolumn{2}{|c|}{ S1b } & \multicolumn{2}{|c|}{ S4a } & \multicolumn{2}{|c|}{ S4b } & & & \multicolumn{2}{|c|}{ S5a } & \multicolumn{2}{|c|}{ S5b } & & \\
\hline & & f & $\%$ & $\mathbf{f}$ & $\%$ & f & $\%$ & $\mathbf{f}$ & $\%$ & Düze & & f & $\%$ & f & $\%$ & f & $\%$ \\
\hline \multirow{2}{*}{ GA0 } & $\mathbf{a}$ & 1 & 1,22 & 2 & 2,44 & 3 & 3,66 & 1 & 1,22 & \multirow{2}{*}{ GA0 } & $\mathbf{a}$ & 6 & 7,32 & 9 & 11 & \multirow{2}{*}{106} & \multirow{2}{*}{21,54} \\
\hline & b & 16 & 19,5 & 17 & 20,7 & 7 & 8,54 & 3 & 3,66 & & b & 22 & 26,8 & 19 & 23,2 & & \\
\hline \multirow{4}{*}{ GA1 } & $\mathbf{a}$ & 1 & 1,22 & 21 & 25,6 & 4 & 4,88 & 5 & 6,1 & \multirow{4}{*}{ GA1 } & & \multirow{4}{*}{8} & \multirow{4}{*}{9,76} & \multirow{4}{*}{10} & \multirow{4}{*}{12,2} & \multirow{4}{*}{113} & \multirow{4}{*}{22,97} \\
\hline & b & 0 & 0 & 1 & 1,22 & 0 & 0 & 3 & 3,66 & & & & & & & & \\
\hline & c & 21 & 25,6 & 3 & 3,66 & 20 & 24,4 & 8 & 9,76 & & & & & & & & \\
\hline & d & 3 & 13,66 & 0 & 0 & 1 & 1,22 & 4 & 4,88 & & & & & & & & \\
\hline \multirow{2}{*}{ GA2 } & $\mathbf{a}$ & 1 & 1,22 & 5 & 6,1 & 3 & 3,66 & 1 & 1,22 & \multirow{2}{*}{ GA2 } & & \multirow{2}{*}{14} & \multirow{2}{*}{17,1} & \multirow{2}{*}{12} & \multirow{2}{*}{14,6} & \multirow{2}{*}{37} & \multirow{2}{*}{7,52} \\
\hline & b & 0 & 0 & 0 & 0 & 0 & 0 & 1 & 1,22 & & & & & & & & \\
\hline GA3 & & 29 & 35,4 & 7 & 8,54 & 35 & 42,7 & 27 & 32,9 & GA3 & & 5 & 6,1 & 4 & 4,88 & 107 & 21,75 \\
\hline GA4 & & 10 & 12,2 & 26 & 31,7 & 9 & 11 & 29 & 35,4 & GA4 & & 27 & 32,9 & 28 & 34,1 & 129 & 26,22 \\
\hline
\end{tabular}

Tablo 4'te görüldüğü gibi öğretmen adaylarının yaklaşık \%48'i GA3 ve GA4 olmak üzere limit kavramına yönelik grafiksel anlama bakımından üst düzeylerde yoğunlaşmıştır. Her bir düzey incelendiğinde öğretmen adaylarının yaklaşık \%26'sının en üst düzey olan GA4 düzeyinde, yaklaşı \%22'sinin ise GA3 düzeyinde yer aldığı görülmektedir. GA0 ve GA1 düzeyleri ele alındığında öğretmen adaylarının yaklaşı \%45'inin grafiksel anlama bakımından alt düzeylerde yoğunlaştı̆̆ı dikkat çekmektedir. Dolayısıyla öğretmen adaylarının büyük bir çoğunluğunun ya üst düzeylerde ya da alt düzeylerde grafiksel anlamaya sahip olduğu fark edilmektedir. 
Yaklaşık \%8 olmak üzere oldukça küçük bir kısmı ise GA2 düzeyinde olup orta düzeyde bir grafiksel anlamaya sahiptir.

Öğretmen adaylarının grafiksel anlama bakımından GA4 düzeyinde yoğunlaşmalarının açık uçlu sınavda yer alan S1b, S4b, S5a ve S5b sorularına verdikleri yanıtlarla kaynaklandığı fark edilmektedir. Öğretmen adaylarının büyük bir kısmının $(\% 35,4)$ limitin varlığını ifade etme ve yeterli gerekçe sunma açısından doğru yanıtladığı S4b ile ilgili örnek çözüm Şekil 2'de yer almaktadır.

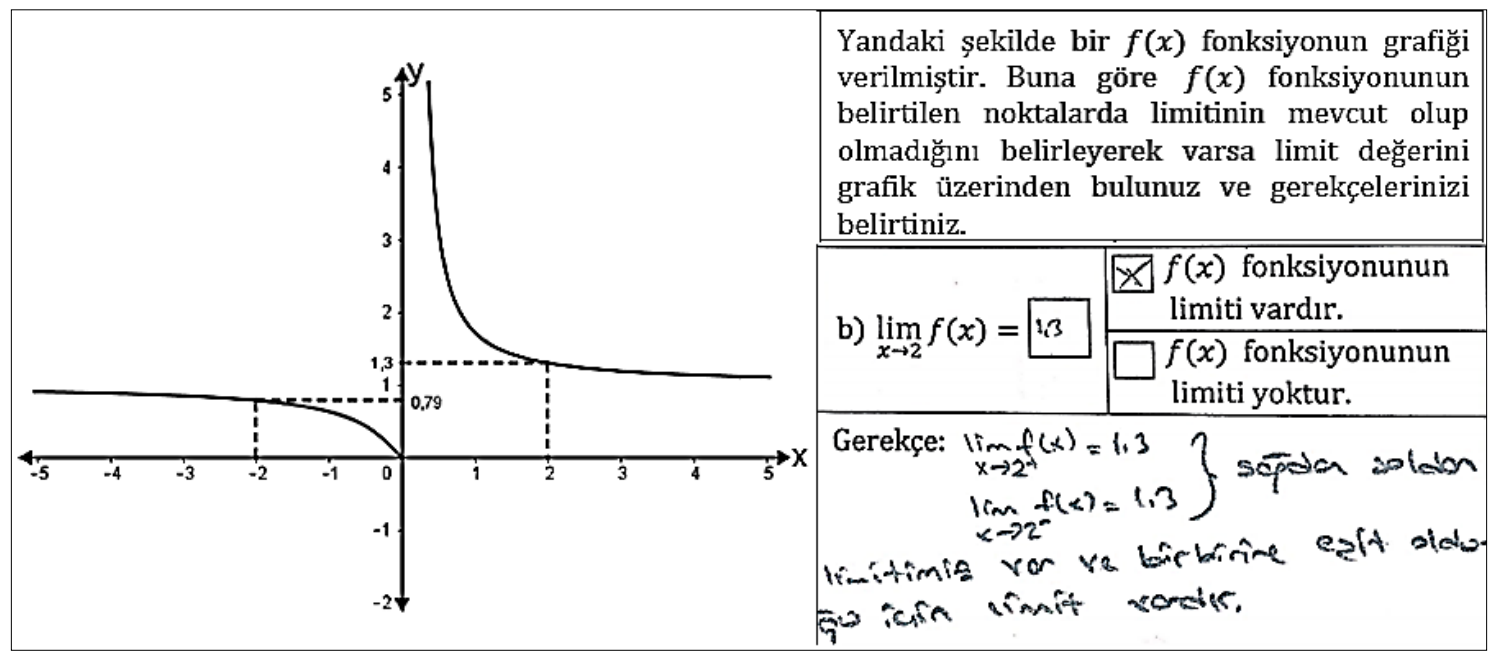

Şekil 2. S4b ile ilgili GA4 düzeyine yönelik örnek çözüm

Şekil 2'de görüldüğü gibi öğretmen adayı belirtilen nokta için grafik üzerinde sağdan ve soldan incelemeler yaparak limit varlığına yönelik doğru bir karar vermiştir. Ayrıca limit değerini doğru ifade ederek yeterli bir gerekçe sunmuştur. Böylece öğretmen adayı grafiksel anlama bakımından GA4 düzeydeki göstergelere uygun bir çözüm gerçekleştirmiştir.

Grafiksel anlama düzeylerinden GA3'e yönelik yanıtlar çoğunlukla $(\% 42,7)$ S4a sorusunun çözümünde ortaya çıkmıştır. Bu düzeye ilişkin örnek çözüm Şekil 3 ’te verilmiştir.

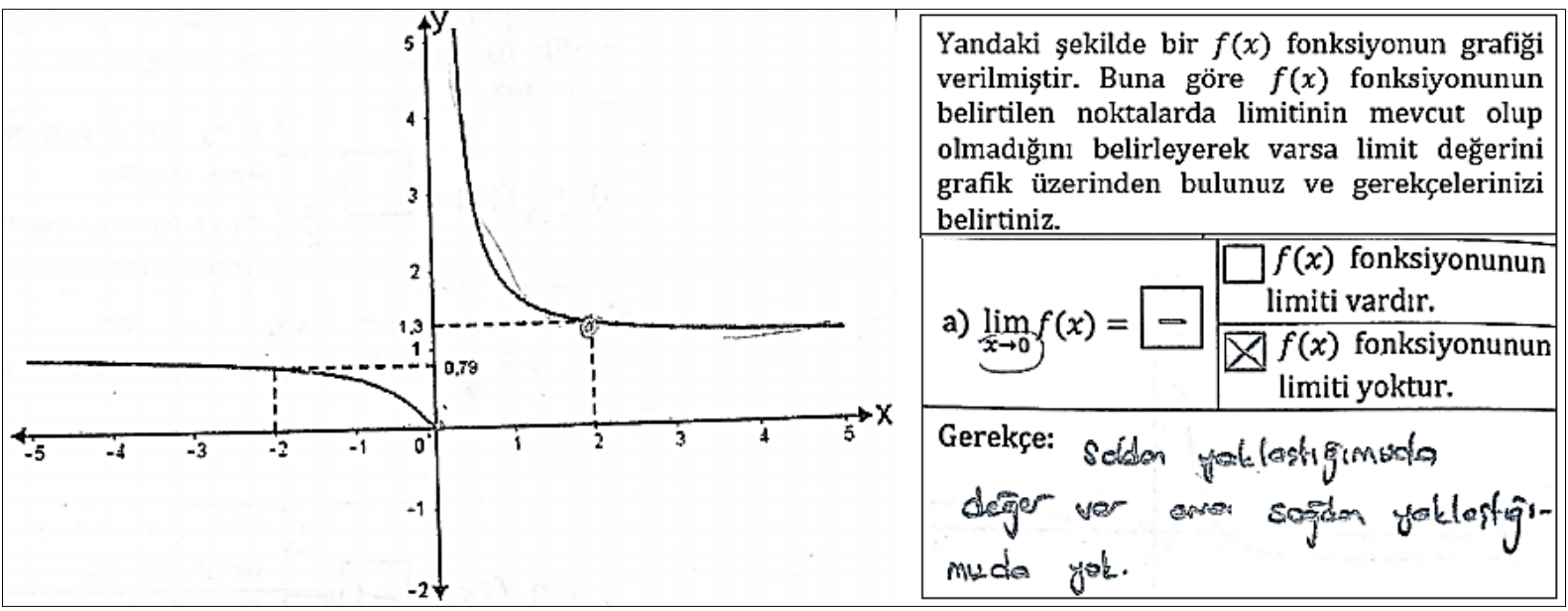

Şekil 3. S4a ile ilgili GA3 düzeyine yönelik örnek çözüm

Şekil 3 'te öğretmen adayı limitin varlığına yönelik uygun bir karar vererek doğru limit değerini belirtmiş; ancak yeterli olmayan bir gerekçe sunmuştur. $\mathrm{Bu}$ çözümde gerekçesinin yeterli olmamasının nedeni, ilgili noktaya soldan yaklaştığında var olduğunu ileri sürdüğü değerin hangi sayıya eşit olduğunu belirtmemesi ve sağdan yaklaştığında limit değerinin olmamasını sonucun sonsuz çıkmasıyla ilişkilendirememesidir.

Öğretmen adaylarının grafiksel anlama bakımından GA0 düzeyinde yoğunlaştığı sorular S5a ve S5b'dir. Bununla birlikte S1a ve S1b sorularında da dikkate değer oranda (sırasıyla \%19,5 ve \%20,7) bir yoğunlaşma söz konusudur. Aynı sorularda öğretmen adaylarının büyük bir çoğunluğunun $(\% 25,6)$ GA1 düzeyinde yanıtlar verdiği fark edilmiştir. Limitin varlığını, limit değerini ve gerekçeyi yanlış ifade eden iki farklı öğretmen adayının GA0 düzeyine uygun çözümleri Şekil 4’te sunulmuştur. 


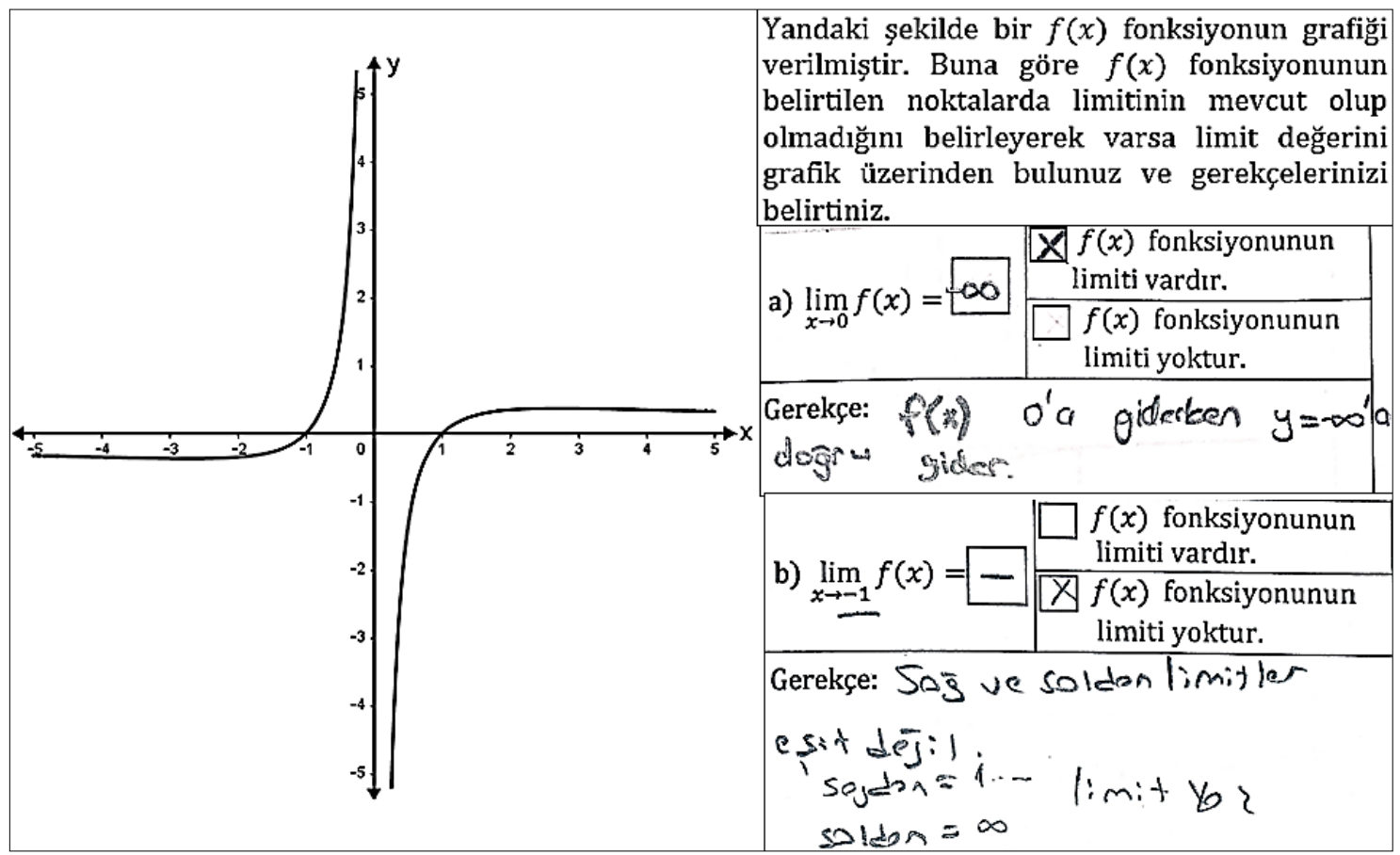

Şekil 4. S1a ve S1b ile ilgili GA0 düzeyine yönelik örnek çözümler

Şekil 4'te görüldüğü üzere S1a sorusunda öğretmen adayı reel sayılar kümesinde bir fonksiyonun limit değerinin sonsuz olabileceğini düşünerek limitin varlığına yönelik yanlış bir karar vermiştir. Ayrıca ilgili noktaya sağdan ve soldan yaklaşırken sırasıyla $-\infty$ ve $+\infty$ sonuçlarına ulaşıldığından fonksiyonun limitinin mevcut olmadığ 1 şeklinde bir gerekçe sunamamıştır. Öğretmen adayı, S1b sorusunda ilgili noktada fonksiyonun sağdan ve soldan limitini grafik üzerinde incelerken sırasıyla limit değerlerini 1 ve $\infty$ bularak limitin olmadığına karar vermiştir. Öğretmen adayından beklenen yanıt ise ilgili noktada limitin mevcut olduğu ve değerinin 0 olduğudur.

Öğretmen adaylarının grafiksel anlama bakımından en az GA2 düzeyine uygun yanıtlar verdiği görülmüştür. Limit değerini doğru ifade ederek bununla ilgili yanlış gerekçe sunan (S5a) ya da herhangi bir gerekçe sunmayan (S5b) iki öğretmen adayının GA2 düzeyine uygun çözümleri Şekil 5'te sunulmuştur.

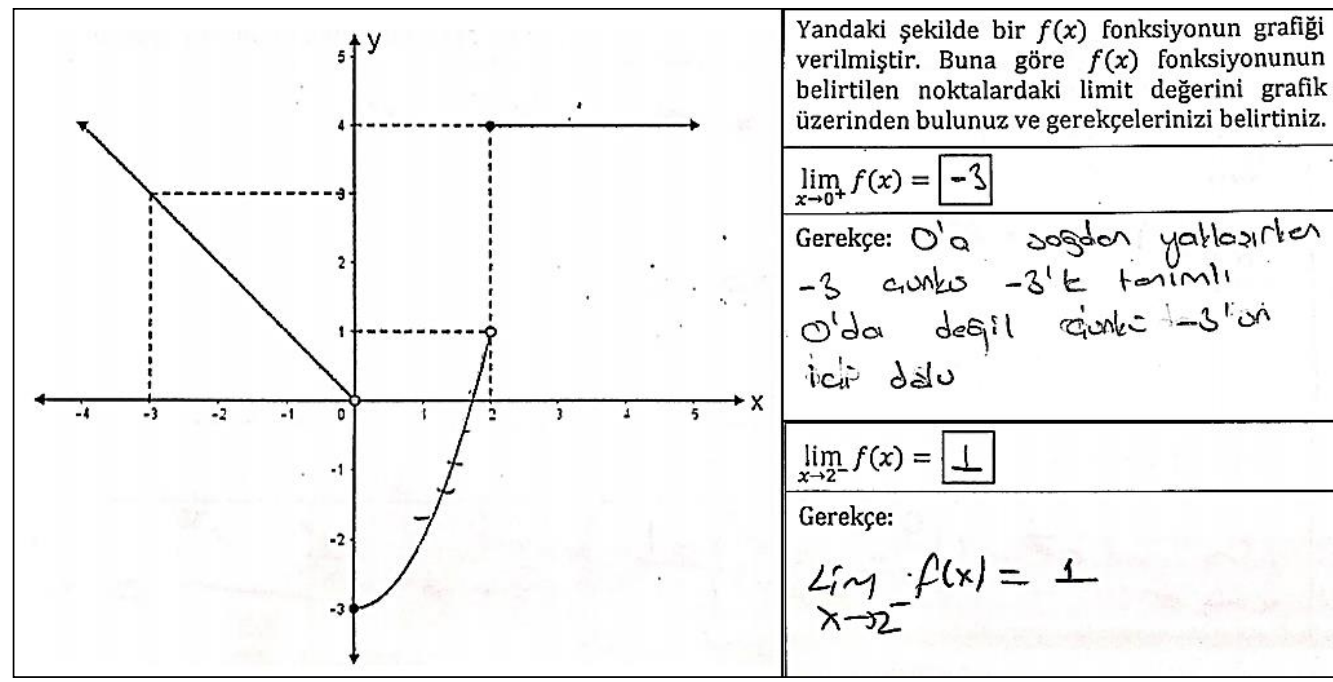

Şekil 5. S5a ve S5b ile ilgili GA2 düzeyine yönelik örnek çözümler

Şekil 5'te görüldüğü gibi öğretmen adayı S5a sorusunda ilgili noktanın sağdan limit değerini doğru belirtmesine rağmen sunduğu gerekçe yeterli değildir. Öğretmen adayı, fonksiyonun bir noktadaki limit değerinin o noktada tanımlı olması gerektiğine işaret eden bir gerekçe sunmuştur. Bu durum, öğretmen adayının ilgili noktadaki değerin fonksiyonun değer kümesine dâhil olmasına bağlı olarak karar verdiğini ve kısmen bir gerekçe sunduğunu göstermektedir. S5b sorusunda ise diğer öğretmen adayı fonksiyonun ilgili noktadaki soldan limitini doğru belirtmiş; ancak herhangi bir gerekçe sunmamıştır. 


\section{2.Öğretmen Adaylarının Limit Kavramına Yönelik Cebirsel Anlama Düzeyleri ile İlgili Bulgular}

Çalışmada fen bilgisi öğretmen adaylarının cebirsel anlama düzeylerini belirlemeye yönelik sorulara verdiği yanitlar, cebirsel anlama kategorik puanlama cetvelinde yer alan göstergelere göre analiz edilmiştir. Bu analizden elde edilen frekans ve yüzde dağılımı Tablo 5'te sunulmuştur.

Tablo 5. Cebirsel Anlama Düzeyleri ile İlgili Frekans ve Yüzde Dağılımı

\begin{tabular}{|c|c|c|c|c|c|c|c|c|c|c|c|c|c|}
\hline \multirow{3}{*}{\multicolumn{2}{|c|}{$\begin{array}{c}\text { Soru } \\
\text { Düzey }\end{array}$}} & \multirow{2}{*}{\multicolumn{2}{|c|}{ S2 }} & \multicolumn{4}{|c|}{ S6 } & \multirow{2}{*}{\multicolumn{2}{|c|}{ Soru }} & \multirow{2}{*}{\multicolumn{2}{|c|}{ S3 }} & \multirow{2}{*}{\multicolumn{2}{|c|}{ Toplam }} \\
\hline & & & & \multicolumn{2}{|c|}{ S6a } & \multicolumn{2}{|c|}{ S6b } & & & & & & \\
\hline & & f & $\%$ & f & $\%$ & f & $\%$ & \multicolumn{2}{|c|}{ Düzey } & f & $\%$ & f & $\%$ \\
\hline \multirow{4}{*}{ CAO } & $\mathbf{a}$ & 6 & 7,32 & 4 & 4,88 & 6 & 7,32 & \multirow{4}{*}{ CAO } & & & & \multirow{4}{*}{132} & \multirow{4}{*}{40,2} \\
\hline & b & 3 & 3,66 & 4 & 4,88 & 3 & 3,66 & & a & 31 & 37,8 & & \\
\hline & c & 18 & 22 & 1 & 1,22 & 0 & 0 & & & & & & \\
\hline & d & 5 & 6,1 & 5 & 6,1 & 7 & 8,54 & & b & 39 & 47,6 & & \\
\hline \multirow{5}{*}{ CA1 } & $\mathbf{a}$ & 2 & 2,44 & 4 & 4,88 & 3 & 3,66 & \multirow{5}{*}{ CA1 } & & \multirow{5}{*}{4} & \multirow{5}{*}{4,88} & \multirow{5}{*}{78} & \multirow{5}{*}{23,8} \\
\hline & b & 5 & 6,1 & 1 & 1,22 & 3 & 3,66 & & & & & & \\
\hline & c & 0 & 0 & 0 & 0 & 0 & 0 & & & & & & \\
\hline & d & 18 & 22 & 0 & 0 & 0 & 0 & & & & & & \\
\hline & e & 9 & 11 & 13 & 15,9 & 16 & 19,5 & & & & & & \\
\hline \multirow{3}{*}{$\mathrm{CA2}$} & $\mathbf{a}$ & 0 & 0 & 0 & 0 & 0 & 0 & \multirow{3}{*}{\multicolumn{2}{|c|}{$\mathrm{CA} 2$}} & \multirow{3}{*}{2} & \multirow{3}{*}{2,44} & \multirow{3}{*}{13} & \multirow{3}{*}{3,96} \\
\hline & b & 0 & 0 & 0 & 0 & 0 & 0 & & & & & & \\
\hline & c & 7 & 8,54 & 0 & 0 & 4 & 4,88 & & & & & & \\
\hline \multirow{3}{*}{ CA3 } & $\mathbf{a}$ & 9 & 11 & 16 & 19,5 & 13 & 15,9 & \multirow{3}{*}{ CA3 } & & & & \multirow{3}{*}{100} & \multirow{3}{*}{30,5} \\
\hline & b & 0 & 0 & 0 & 0 & 0 & 0 & & a & 0 & 0 & & \\
\hline & c & 0 & 0 & 34 & 41,5 & 27 & 32,9 & & b & 1 & 1,22 & & \\
\hline CA4 & d & 0 & 0 & 0 & 0 & 0 & 0 & CA4 & & 5 & 6,1 & 5 & 1,52 \\
\hline
\end{tabular}

Tablo 5’te görüldüğü üzere öğretmen adaylarının \%64'ü cebirsel anlama bakımından CA0 ve CA1 düzeylerinde yoğunlaşmıştır. Öğretmen adaylarının yaklaşı \%32'sinin ise CA3 ve CA4 düzeylerinde yer aldığı görülmektedir. Bu durum, adayların büyük bir çoğunluğunun limit kavramına yönelik alt düzeyde cebirsel anlamaya sahip olduğunu göstermektedir. Cebirsel anlama bakımından orta düzey olarak nitelendirilen CA2 düzeyinde ise öğretmen adaylarının yaklaşık \%4'ü yer almaktadır. Bu düzey, CA4 düzeyinin $(\% 1,52)$ ardından en düşük yüzdeye sahiptir.

Öğretmen adaylarının cebirsel anlama bakımından CA0 düzeyinde yoğunlaşmalarına açık uçlu sınavda yer alan S3 sorusuna verdikleri yanıtlar yol açmıştır. Bu düzeyde nitelendirilmelerine sebep olan bir diğer soru ise S2'dir. Cebirsel işlemleri yanlış yürüterek limit değerini yanlış ifade eden iki öğretmen adayının S3 sorusuna yönelik çözümleri Şekil 6’da yer almaktadır.

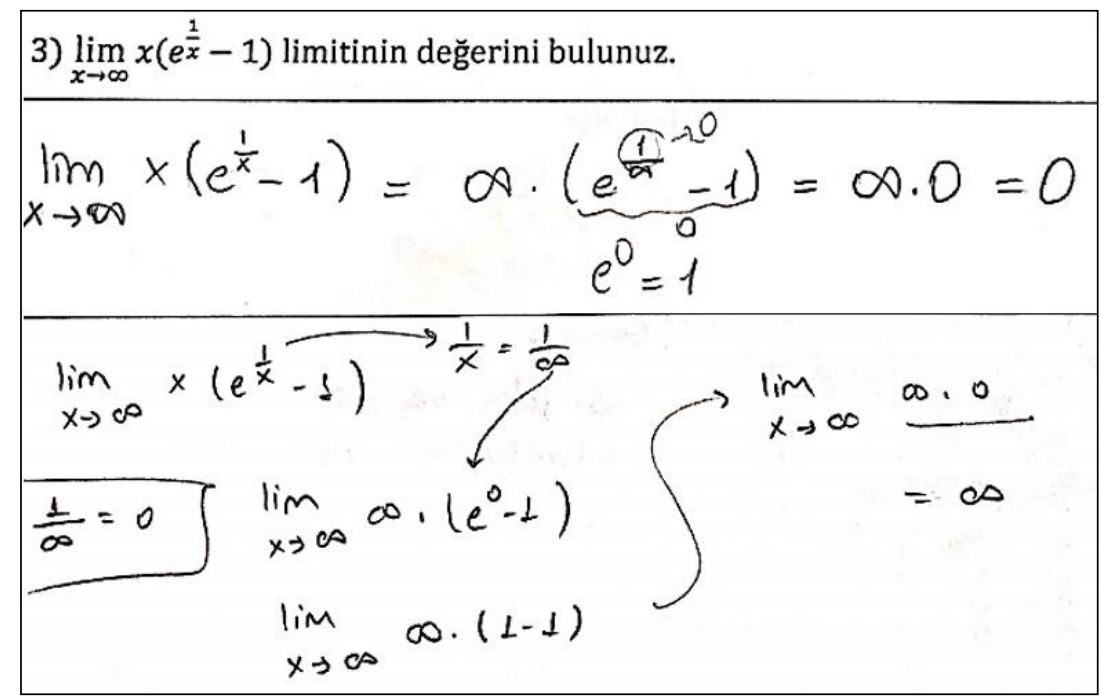

Şekil 6. S3 ile ilgili CA0 düzeyine yönelik örnek çözümler

Şekil 6'da görüldüğü gibi her iki öğretmen adayı cebirsel işlemler yürüterek $0 . \infty$ belirsizliğine ulaşmalarına rağmen bu ifadenin bir belirsizlik durumu olduğunu fark edememişlerdir. Öğretmen adaylarından biri bu 
ifadenin sonucunu "0", bir diğeri ise "ळ" olmak üzere yanlış olarak belirtmiştir. Buna karşın soruda adaylardan beklenen, bu belirsizliği gidermeye yönelik doğru cebirsel işlemler yürütmeleri ve limit değerini "1" olarak bulabilmeleridir.

Cebirsel anlama düzeylerinden CA3, CA0 düzeyinden sonra en yüksek yüzdeye $(\% 30,5)$ sahiptir. Bu düzeye yönelik yanıtlar en çok S6 sorusunda ortaya çıkmıştır ve bu yanıtlar S6a için \%61'lik, S6b için \%48,8'lik bir orana sahiptir. Limitin varlığına yönelik doğru karar vererek kısmen doğru cebirsel işlemlerin yürütülmesiyle doğru limit değerine ulaşan iki farklı öğretmen adayının S6 sorusuna yönelik çözümleri Şekil 7'de yer almaktadır.

6) $f(x)=\left\{\begin{array}{cc}2 \cos x, & x<0 \\ \cos x+1, & 0 \leq x \leq \pi \\ -\sin x, & x>\pi\end{array}\right.$ fonksiyonunun belirtilen noktalarda limitinin mevcut olup olmadığın

belirleyiniz ve varsa limit değerini hesaplayınız.

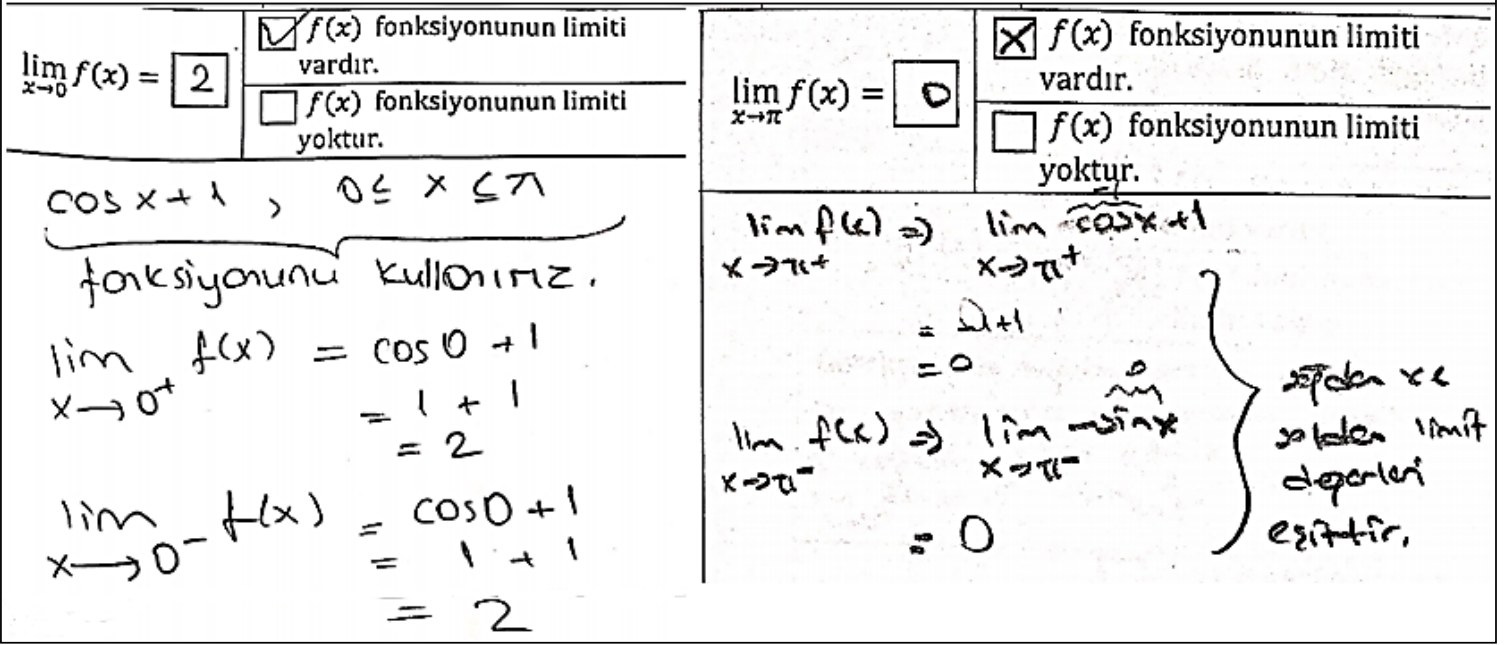

Şekil 7. S6a ve S6b ile ilgili CA3 düzeyine yönelik örnek çözümler

Cebirsel anlamanın en üst düzeyi olan CA4 düzeyine uygun yanıtlar, sadece S6 sorusunda ortaya çıkmıştır. Dolayısıyla bu düzeye yönelik cebirsel anlamaya sahip olan öğretmen adayı sayısı oldukça azdır. Bu düzeyden sonra en düşük yüzdeye sahip anlama düzeyi CA2'dir. Limit varlığına doğru karar veren, kısmen doğru cebirsel işlemler yürüterek yanlış limit değerine ulaşan bir öğretmen adayının CA2 düzeyine uygun çözümü Şekil 8'de yer almaktadır.

2) $f(x)=\frac{\ln |x|}{x}$ fonksiyonunun $x=0$ noktasında limitinin mevcut olup olmadığını belirleyiniz ve varsa limit değerini hesaplayınız.

\begin{tabular}{l|l}
\hline$\square f(x)$ fonksiyonunun limiti vardır. & $\bigotimes f(x)$ fonksiyonunun limiti yoktur. \\
\hline $\lim _{x \rightarrow 0} \frac{\ln |x|}{x}=\frac{\ln |0|}{0}=\frac{\infty}{0} \rightarrow$ Paydası 0 oldugiu icim tanımsızdır.
\end{tabular}

Şekil 8. S2 ile ilgili CA2 düzeyine yönelik örnek çözüm

Şekil 8'de görüldüğü gibi öğretmen adayı fonksiyonun ilgili noktada sağdan ve soldan limitlerini incelemeksizin cebirsel işlemler yürütmüştür. Bu bağlamda öğretmen adayı $\lim _{x \rightarrow 0} \ln |x|$ ifadesinin sonucunun

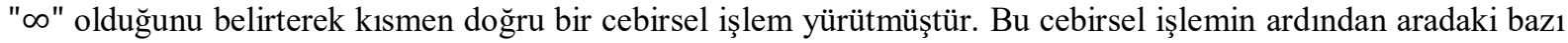
işlem adımlarını yapmaksızın $\frac{\infty}{0}$ ifadesini doğrudan tanımsız olarak niteleyerek limitin varlığına yönelik doğru bir karar vermiştir.

\section{3.Öğretmen Adaylarının Limit Kavramına Yönelik Grafiksel ve Cebirsel Anlama Düzeylerinin Karşılaştırılması}

Öğretmen adaylarının limit kavramına yönelik grafiksel ve cebirsel anlama düzeyleri eş değer sorular dikkate alınarak karşılaştırılmıştır. Bu amaçla her bir soru çiftinin anlama düzeylerine yönelik yüzdeleri belirlenmiştir. 
Buna ek olarak her bir düzey için grafiksel ve cebirsel anlama bakımından yüzdeler belirlenerek karşılaştırmalar yapılmıştır.

Öncelikle öğretmen adaylarının her bir eş değer soru çiftindeki (S1-S2, S4-S3 ve S5-S6) grafiksel ve cebirsel anlama açısından hangi düzeyde yer aldıklarının belirlenmesi amaçlanmıştır. Grafiksel ve cebirsel anlama düzeylerinin eş değer sorular üzerinden karşılaştırılması Tablo 6'da verilmiştir.

Tablo 6. Anlama Düzeylerinin Eş Değer Sorular Üzerinden Karşılaştırılması

\begin{tabular}{ccccccc}
\hline \multirow{2}{*}{$\begin{array}{c}\text { Grafiksel - Cebirsel } \\
\text { Anlama Düzeyleri }\end{array}$} & GA & CA & GA & CA & GA & CA \\
\cline { 2 - 7 } & S1 (\%) & S2 (\%) & S4 (\%) & S3 (\%) & S5 (\%) & S6 (\%) \\
\hline 0. Düzey & 21,95 & 39,02 & 8,54 & 85,37 & 34,15 & 18,29 \\
\hline 1. Düzey & 30,49 & 41,46 & 27,44 & 4,87 & 10,98 & 24,39 \\
\hline 2. Düzey & 3,66 & 8,54 & 3,05 & 2,44 & 15,85 & 2,44 \\
\hline 3. Düzey & 21,95 & 10,98 & 37,8 & 1,22 & 5,48 & 54,88 \\
\hline 4. Düzey & 21,95 & 0 & 23,17 & 6,1 & 33,54 & 0 \\
\hline
\end{tabular}

Tablo 6'da görüldüğü gibi öğretmen adaylarının genel anlamda eş değer sorularda belirtilen fonksiyonun limit değerini grafik üzerinden doğru bir şekilde belirleyebildikleri fark edilmiştir. Dolayısıyla adayların eş değer soru çiftlerinden ilk ikisinde (S1 ve S2 ile S4 ve S3) grafiksel anlamaya yönelik olan sorularda (S1 ve S4) daha üst düzeyde yer aldıkları görülmektedir. Ancak S5 ve S6'da grafiksel anlama bakımından yaklaşık \%39'u; cebirsel anlama bakımından ise yaklaşık \%55'i üst düzeylerde yer almaktadır. Bu durum son eş değer soru çiftinde adayların cebirsel anlama bakımından daha üst düzeyde yer aldığını göstermektedir. Her ne kadar bu soru çiftinde adaylar cebirsel anlama bakımından daha üst düzeyde yer alsalar da (CA3 düzeyinde \%54,88) en üst düzey olan CA4 düzeyinde $(\% 0)$ yanıt verememişlerdir.

Öğretmen adaylarının limit kavramına yönelik anlama düzeylerinin grafiksel ve cebirsel açıdan karşılaştırılması Grafik 1'de sunulmuştur.

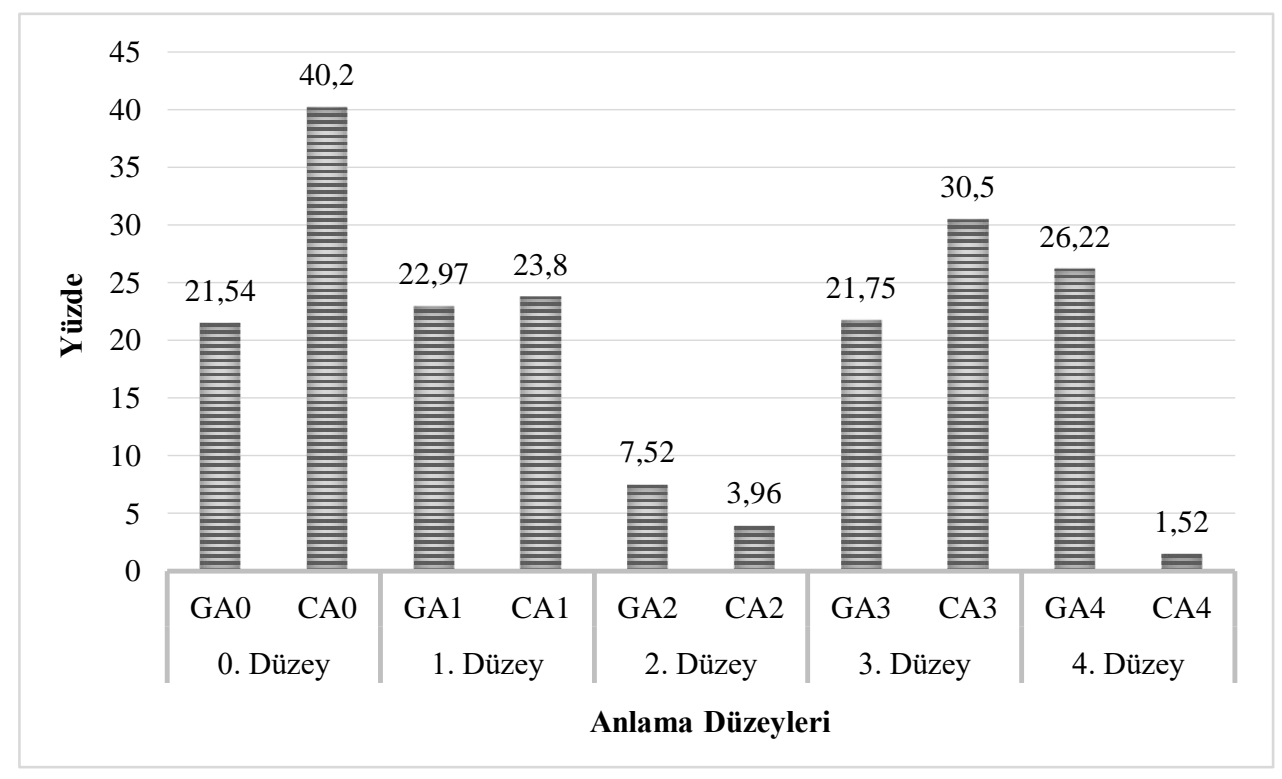

Grafik 1. Anlama düzeylerinin grafiksel ve cebirsel yönden karşılaştırılması

Grafik 1'de görüldüğü gibi her bir anlama düzeyi grafiksel ve cebirsel yönden incelendiğinde limite yönelik cebirsel anlamanın genel olarak alt düzeylerde daha yüksek olduğu fark edilmektedir. Anlama düzeylerinden en alt düzey olarak nitelendirilen 0 . düzeyde limite yönelik cebirsel anlama oranının grafiksel anlama oranına göre yüksek (GA0: \%21,54; CA0: \%40,2) olduğu göze çarpmaktadır. Bu durum, öğretmen adaylarının cebirsel anlama bakımından daha alt düzeyde olduklarına işaret etmektedir. Üst düzeylerde ise grafiksel anlamanın daha yüksek oranlarda olduğu görülmektedir. Özellikle de 4. düzeyde öğretmen adaylarının limite yönelik grafiksel anlamalarının cebirsel anlamaya göre oldukça yüksek bir orana (GA4: \%26,22; CA4: \%1,52) sahip olduğu dikkat çekmektedir. Dolayısıyla öğretmen adaylarının limite yönelik grafiksel anlamalarının cebirsel anlamalarına göre daha ön planda olduğu görülmektedir.

\section{Tartışma, Sonuç ve Öneriler}

$\mathrm{Bu}$ çalışma ile fen bilgisi öğretmen adaylarının limit kavramına yönelik grafiksel ve cebirsel anlama düzeylerini incelemek amaçlanmıştır. $\mathrm{Bu}$ amaç doğrultusunda öğretmen adaylarına açık uçlu bir sınav 
uygulanarak grafiksel ve cebirsel anlama düzeyleri belirlenmiştir. Araştırmanın bulgularına dayalı olarak öğretmen adaylarının limit kavramına yönelik grafiksel anlamalarının genel olarak üst düzeyde yer aldığı sonucuna ulaşılmıştır. Bununla birlikte adayların cebirsel anlamalarının alt düzeyde olduğu belirlenmiştir. Bu durum öğretmen adaylarının bir fonksiyonun limit değerini, grafiği üzerinden kolaylıkla belirleyebilirken cebirsel işlemleri genel anlamda doğru bir şekilde yürüterek limit değerine ulaşamadıklarına işaret etmektedir. Fen bilgisi öğretmen adaylarının fizik, kimya, biyoloji gibi alan derslerinde sıklıkla grafikler üzerinden yorumlamalar yapmalarını gerektiren durumlarla karşılaşmaları grafiksel anlamalarının daha üst düzeyde olmasına katkıda bulunmuş olabilir. Fen derslerinde öğrenmeleri kolaylaştırmak ve öğrenilenlerin kalıcılığını arttırmak için grafikler sıklıkla kullanılan somut materyallerden biridir (Taşdemir, Demirbaş ve Bozdoğan, 2005). Taşar, İngeç ve Güneş (2002) fen bilimleri derslerinde deney yaparken grafik çizme ve anlama becerisinin deneyden sonuç elde etme sürecindeki önemine vurgu yapmışlardır. Verileri kaydetme, sınıflandırma, aralarındaki belirgin ilişkileri bulma ve sonuçları sunma aşamalarında grafik çizme ve yorumlamanın özellikle laboratuvar derslerinde yapılan deneylerde sıklıkla kullanıldığını ifade etmişlerdir. Grafiklerin iki ya da daha fazla değişken arasındaki ilişkinin özetini sunarak somutlaştırdığını belirten Bowen ve Roth (2003), grafiklerin fen bilimleri için çok temel bir somutlaştırma aracı olduğuna vurgu yapmıştır. Bu çalışma ile elde edilen 'fen bilgisi öğretmen adaylarının grafiksel anlamalarının üst düzeyde olması' sonucuna bir gerekçe sunması bakımından Bowen ve Roth (2003) tarafindan dile getirilen ifadeler önemlidir. Ayrıca bir fonksiyonun grafiğinin o fonksiyonun ilgili nokta civarındaki davranışı hakkında görsel olarak somut veriler sunması, adayların grafiksel anlamalarının daha üst düzeyde çıkmasını desteklemiş olabilir. Nitekim, Arslan ve Çelik (2013) limitin formal tanımına geçmeden önce belirli bir nokta civarındaki fonksiyonun davranışına yönelik kavramsal temel oluşturmada tablo ve grafiklerin incelenmesinin önemine işaret etmiştir. Sezgisel tanımın oluşturulması için önemli olan tablo ve grafik inceleme yaklaşımının genel matematik dersinde kullanılmasının adayların grafiksel anlamalarının daha üst düzeyde çıkmasına yol açan nedenlerden biri olduğu söylenebilir. Bununla birlikte limitin sezgisel tanımını anlamada öğrencilerin daha başarılı olduğunu belirtilen çalışmaların mevcut olması (Cottrill ve ark., 1996; İ. Çetin, 2009) bu sonucu destekler niteliktedir. Öğretmen adaylarının grafiksel anlama bakımından üst düzeyde yer almaları, grafik üzerinden ilgili noktadaki limit değerini sağdan ve soldan doğru belirleyerek fonksiyonun limitinin varlı̆̆ına yönelik doğru bir karar verebildikleri ve uygun gerekçeler sunabildikleri anlamına gelmektedir.

Öğretmen adaylarının bir fonksiyonun limitinin bir reel sayı civarında sağdan veya soldan sonsuz çıkması durumunda limitin varlığına karar grafik üzerinden vermelerinin daha zor olduğu belirlenmiştir. Buna karşın bir fonksiyonun limitinin bir reel sayı civarında değerinin yine bir reel sayı çıkması durumunda limitin varlığına çok daha kolay karar verebildikleri tespit edilmiştir. Bu sonucun ortaya çıkması, sonsuzluk kavramının öğrencilerin zihinlerinde tam olarak yer etmemesine bağlı olabilir. Özmantar (2013) öğretim programlarında okul öncesinden üniversite düzeyine sonsuzluk kavramına yer verilmesine karşın öğrencilerin her düzeyde bu kavramı anlamlandırmakta zorluk yaşadığını ifade etmiştir. Singer ve Voica (2003) ilköğretim düzeyindeki öğrencilerin sonsuzluk kavramına yönelik sezgisel kavrayışlarının bu kavramın gerçek anlamının yapılandırılmasının önünde bir engel olduğunu dile getirmiştir. Tsamir ve Dreyfus (2002) ise lise ve üniversite düzeyindeki öğrencilerin sonsuzluk kavramına dair tutarlı olmayan fikirleri olduğunu belirtmiştir. Dolayısıyla bu çalışmada fen bilgisi öğretmen adaylarının sonsuzluk kavramını içselleştirememelerine bağlı olarak bir fonksiyonun sağdan veya soldan limitinin sonsuz çıkması durumunda limit değerine doğru karar verememiş olabilirler. Limit kavramının anlaşılmasında epistemolojik bir engel olarak sonsuzluk kavramını ifade eden çalışmaların (Elia ve ark., 2009; Sierpinska, 1987) mevcut olması da bu sonucu açıklar niteliktedir.

Parçalı fonksiyon grafiği üzerinde bir fonksiyonun limitin varlığına karar verme ve limit değerini bulma açısından öğretmen adaylarının grafiksel anlamalarının daha üst düzeyde olduğu ortaya çıkmıştır. Bu durumun ortaya çıkma nedenlerinden biri öğretmen adaylarının önceki öğrenimlerinde parçalı fonksiyon ve bu fonksiyon üzerinde yapılan işlemlerle daha sık karşılamaları olabilir. Diğer bir neden ise hem lise hem de lisans düzeyinde fonksiyonların sağdan ve soldan limit değerlerinin incelenmesinin genellikle parçalı fonksiyon örnekleri üzerinden yapılması olabilir. Buna ek olarak grafiksel anlamayı belirlemeye yönelik parçalı fonksiyon sorusunda limitin tek yönden (sadece sağdan ya da soldan) incelenerek değerinin sonlu bir reel sayı çıkması, adayların ilgili soruda grafiksel anlamalarının daha üst düzeyde çıkmasına neden olmuş olabilir.

Parçalı fonksiyon grafiklerinde belirli bir noktanın komşuluğunda limit değeri incelenirken bir yönden sonsuz çıkması adaylar için genellikle zorluk oluşturmuştur. Ancak açık uçlu sinavdaki parçalı fonksiyon sorusunda limit değerinin reel bir sayı çıkması da adayların grafiksel anlamalarının daha üst düzeyde yer almalarına neden olmuş olabilir. Parçalı fonksiyon sorusunda grafiksel anlamaları üst düzey çıkmasına rağmen öğretmen adaylarının zorluk yaşadığı bir durum da belirlenmiştir. Limitin incelendiği noktada tanımlı olmasına gerek olmadığı bilgisini göz ardı eden adaylar, fonksiyonun limit değerini belirlerken sürekliliğini inceleme girişiminde bulunarak yanılgıya düşmüşlerdir.

Öğretmen adaylarının cebirsel anlama bakımından alt düzeyde olmaları, cebirsel işlemleri doğru bir şekilde yürütemedikleri, limitin varlığına yönelik doğru bir karar veremedikleri ve bunun sonucunda doğru bir limit 
değerine ulaşamadıkları anlamına gelmektedir. Fen bilgisi öğretmen adaylarının grafik okuma ve yorumlamaya daha eğilimli olmaları cebirsel anlamalarının alt düzeyde çıkmasına sebep olmuş olabilir. Baki ve Çekmez (2012) matematik öğretmen adaylarına limitin formal tanımının öğretiminde cebirsel gösterimlerin grafiklerle desteklenmesi gerektiğini vurgulamışlardır. Fen bilgisi öğretmen adaylarına ise limitin sezgisel tanımının öğretiminde grafiklerin kullanımının yanı sıra cebirsel işlemler yapmaya da özen gösterilmelidir. Benzer şekilde Fernandez (2004) matematik öğretmen adaylarına limitin formal tanımını doğrudan vermek yerine tek bir örnek üzerinden hem grafiksel hem de cebirsel incelemelerle fonksiyonların formal tanımı üzerinde tartışmalarını sağlamıştır. Bu bakımından fen bilgisi öğretmen adaylarına da limit öğretimi yapılırken aynı örnek üzerinden hem grafiksel hem de cebirsel incelemelerle limit değerini belirlemelerine imkân sağlayacak öğrenme ortamları oluşturulabilir. $\mathrm{Bu}$ durum fen bilgisi öğretmen adaylarının limiti kavramsal olarak anlamalarına katkı sağlayabilir.

Adayların cebirsel anlamalarının alt düzeyde olduğu sorulardan birinin belirsizlik durumuna yönelik olan soru olduğu tespit edilmiştir. Bununla birlikte logaritma ve mutlak değer fonksiyonlarını içeren rasyonel fonksiyonun limit değerini bulmaya yönelik olan soruda da cebirsel anlamanın alt düzeyde olduğu belirlenmiştir. Adayların açık uçlu sınavda yer alan $0 . \infty$ belirsizlik durumunda gerekli cebirsel işlemleri yürütememeleri, önceki öğrenimlerinde daha çok $\frac{0}{0}$ ve $\frac{\infty}{\infty}$ belirsizlik durumlarına aşina olmalarından kaynaklanabilir. Özmantar ve Yeşildere (2010) öğrencilerin limit alırken karşılaştıkları bazı belirsizlik durumlarında bu belirsizliği gidermek için gereken işlemleri yürütemediklerini belirtmiştir. Aslında bir belirsizlik durumunda limiti bulmak için yürütülmesi gereken işlemler cebirsel anlamanın temelini oluşturan adımlardır. Rasyonel fonksiyon ile ilgili sorunun yeterli ölçüde yapılamama sebepleri ise adayların logaritma ve mutlak değer fonksiyonlarına yönelik tanım bilgisindeki eksiklikleri ve bu fonksiyonlara yönelik cebirsel işlemlerde daha az deneyime sahip olmaları olabilir. Bukova (2006) bir fonksiyonun türü değiştikçe öğrencilerin limit alırken yaşadıkları zorlukların arttığını belirtmiştir. Ayrıca farklı fonksiyon türleri ile deneyime sahip olmayan öğrencilerin limit, süreklilik, türev gibi kavramlarda fonksiyon türüne bağlı olarak sorun yaşadıklarına işaret etmesi elde edilen bu sonucu desteklemektedir. Açık uçlu sınavın cebirsel anlamaya yönelik bir diğer sorusu olan parçalı fonksiyonda ise adaylar cebirsel işlemleri doğru bir şekilde yürütebilmiştir. Bu durum, limitin sağdan ve soldan iki aşamalı olarak incelenme sürecinin parçalı fonksiyonun doğasıyla benzerlik göstermesinden kaynaklanabilir. Bununla birlikte grafikler üzerinden olduğu gibi cebirsel işlemler aracılığıyla fonksiyonların sağdan ve soldan limitinin incelenmesinde genellikle parçalı fonksiyonlara yönelik örneklerin tercih edilmesi bu durumun oluşmasına sebep olmuş olabilir.

Açık uçlu sınavda yer alan eş değer sorular üzerinden adayların grafiksel ve cebirsel anlamaları kıyaslandığında düzeyler bakımından önemli farklılıkların olduğu tespit edilmiştir. Rasyonel fonksiyonun cebirsel formunda anlama bakımından üst düzeydeki öğretmen adaylarının oranının aynı sorunun grafiksel formunda üst düzeylere ulaşan adayların oranına göre oldukça az olduğu belirlenmiştir. Benzer durum, belirsizlik durumuna yönelik sorunun grafiksel ve cebirsel formundan elde edilen sonuçlarda da gözlenmiştir. Buna karşın cebirsel olarak ifade edilen parçalı fonksiyon sorusunda adayların anlama bakımından üst düzeylere ulaşabildikleri belirlenmiştir. Dolayısıyla adayların cebirsel anlama bakımından üst düzeye yalnızca bu soruya verdikleri yanıtlarla ulaşabildikleri tespit edilmiştir. Bu çalışmayla fen bilgisi öğretmen adaylarının grafiksel ve cebirsel anlamaları incelenerek mevcut durumun betimlemesi yapılmıştır. Bu çalışmadan elde edilen sonuçların limit kavramına yönelik yapılacak bir öğretimde fen bilgisi öğretmen adaylarının grafiksel ve cebirsel anlamalarını desteklemek adına öğretimdeki uygulamalara yönelik öğretim üyelerine fikir vereceği düşünülmektedir. Bu çalışma kapsamında öğretim sürecine herhangi bir müdahalede bulunmaksızın bir anlamda "mevcut durumun fotoğrafı" çekilmiştir. İleride yapılacak çalışmalarda her iki anlama düzeyini destekleyecek müdahaleler aracılı̆̆ıla (ör. ögrenme ortamları tasarımı) adayların anlama düzeylerinde nasıl bir değişiklik olduğu daha derinlemesine incelenebilir.

\section{Kaynaklar / References}

Akpınar, E. ve Ergin, Ö. (2004). Fen öğretiminde fizik, kimya ve biyolojinin entegrasyonuna yönelik örnek bir uygulama. Marmara Üniversitesi Atatürk Ĕ̆itim Fakültesi Eğitim Bilimleri Dergisi, 19, 1-16.

Arslan, S. ve Çelik, D. (2013). Zor sanılan iki kavram: Limit ve süreklilik. İ. Ö. Zembat, M. F. Özmantar, E. Bingölbali, H. Şandır ve A. Delice (Ed.), Tanımları ve tarihi gelişimleriyle matematiksel kavramlar içinde (ss. 463-487). Ankara: Pegem Akademi.

Baki, M. ve Çekmez, E. (2012). İlköğretim matematik öğretmeni adaylarının limit kavramının formal tanımına yönelik anlamalarının incelenmesi. Türk Bilgisayar ve Matematik Ĕgitimi Dergisi, 3(2), 81-98.

Bardak, Ş. ve Karamustafaoğlu, O. (2016). Fen bilimleri öğretmenlerinin kullandıkları öğretim strateji, yöntem ve tekniklerin pedagojik alan bilgisi bağlamında incelenmesi. Amasya Üniversitesi Eğitim Fakültesi Dergisi, $5(2), 567-605$. 
Baştürk, S., \& Dönmez, G. (2011). Mathematics student teachers' misconceptions on the limit and continuity concepts. Necatibey Faculty of Education Electronic Journal of Science and Mathematics Education, 5(1), 225-249.

Biber, A. Ç. ve Argün, Z. (2015). Matematik öğretmen adaylarının tek ve iki değişkenli fonksiyonlarda limit konusunda sahip oldukları kavram bilgileri arasındaki ilişkilerin incelenmesi. Bartın Üniversitesi Ë̆itim Fakültesi Dergisi, 4(2), 501-515.

Bowen, G. M., \& Roth, W. M. (2003). Graph interpratation practises of science and education majors. Canadian Journal of Science, Mathematics and Technology Education, 3(4), 499-512.

Bukova, E. (2006). Öğrencilerin limit kavramını anlamasında ve diğer kavramların ilişkilendirilmesinde karşılaştıkları güçlükleri ortadan kaldıracak yeni bir program geliştirme (Yayınlanmamış doktora tezi). Dokuz Eylül Üniversitesi, Eğitim Bilimleri Enstitüsü, İzmir.

Cornu, B. (2002). Limits. In D. Tall (Ed.), Advanced mathematical thinking (pp. 153-166). New York, United States of America: Kluwer Academic Publishers.

Cottrill, J., Dubinsky, E., Nichols, D., Schwinngendorf, K., Thomas, K., \& Vidakovic, D. (1996). Understanding the limit concept: Beginning with a coordinated process schema. Journal of Mathematical Behavior, 15, 167192.

Çetin, İ. (2009). Students' understanding of limit concept: An APOS perspective (Unpublished doctoral dissertation). Middle East Technical University, Institute of Science, Ankara.

Çetin, N. (2009). The performance of undergraduate students in the limit concept. International Journal of Mathematical Education in Science and Technology, 40(3), 323-330.

Çıldır, S. (2012). Limit konusunun bilgisayar ortamında görselleştirilmesi ve fizik öğretmen adaylarının konu hakkındaki görüşleri. Hacettepe Üniversitesi Eğitim Fakültesi Dergisi, 42, 143-153.

Davis, P. J., Hersh, R., \& Marchisotto, E. A. (2015). Tüm yönleriyle matematiksel deneyim (Soner Durmuş \& İlksen Oben Eruçar, Çev.). İstanbul: Nobel Akademi Yayıncılık.

Dede, Y. ve Argün, Z. (2004). Matematiksel düşüncenin başlangıç noktası: Matematiksel kavramlar. Kuram ve Uygulamada Ĕ̈itim Yönetimi Dergisi, 10(3), 338-355.

Denbel, D. G. (2014). Students' misconceptions of the limit concept in a first calculus course. Journal of Education and Practice, 5(34), 24-40.

Elia, I., Gagatsis, A., Panaoura, A. Zachariades, T., \& Zoulinaki, F. (2009). Geometric and algebraic approaches in the concept of "limit" and the impact of the "didactic contract". International Journal of Science and Mathematics Education, 7, 765-790.

Ertem-Akbaş, E. (2016). Meslek yüksekokulu ögrrencilerinin bilgisayar destekli ortamda "limit-süreklilik", konusundaki öğrenmelerinin solo taksonomisine göre değerlendirilmesi (Yayınlanmamış doktora tezi). Karadeniz Teknik Üniversitesi, Eğitim Bilimleri Enstitüsü, Trabzon.

Fernandez, E. (2004). The students' take on the epsilon-delta definition of a limit. Primus, 14(1), 43-54.

Fless, M. (1988). An investigation of introductory calculus students' understanding of limits and derivatives. Dissertation Abstracts International, 49, 892A. (University Microfilms No. 89-13, 171).

Kepçeoğlu, İ. ve Yavuz, İ. (2016). GeoGebra yazılımıyla limit ve süreklilik öğretiminin öğretmen adaylarının başarısına etkisi. Necatibey Ĕ̆itim Fakültesi Elektronik Fen ve Matematik Ĕ̆itimi Dergisi, 11(1), 21-47.

Lee, B. S. (1992). An investigation of prospective secondary mathematics teachers' understanding of the mathematical limit concept. Unpublished doctoral dissertation. Michigan State University, Michigan.

Merriam, S. B. (2015). Nitel araştırma: Desen ve uygulama için bir rehber (S. Turan, Çev. Ed.). Ankara: Nobel Yayıncilik.

Millî Eğitim Bakanlığı [MEB]. (2005). Ortaöğretim matematik (9. 10. 11 ve 12. sinıflar) dersi öğretim programi. Ankara: MEB.

O'Halloran, K. L. (2015). The language of learning mathematics: A multimodal perspective. The Journal of Mathematical Behaviour, 40, 63-74.

Özmantar, M. F. (2013). Sonsuzluk kavramı: Tarihsel gelişimi, öğrenci zorlukları ve çözüm önerileri. M. F. Özmantar, E. Bingölbali ve H. Akkoç (Ed.), Matematiksel kavram yanılgıları ve çözüm önerileri içinde (ss. 151-180). Ankara: Pegem Akademi.

Özmantar, M. F. ve Yeşildere, S. (2013). Limit ve süreklilik konularında kavram yanılgıları ve çözüm arayışları. M. F. Özmantar, E. Bingölbali ve H. Akkoç (Ed.), Matematiksel kavram yanılgıları ve çözüm önerileri içinde (ss. 181-221). Ankara: Pegem Akademi.

Öztürk, T. (2016). Matematik öğretmeni adaylarının ispatlama becerilerini geliştirmeye yönelik tasarlanan öğrenme ortamının değerlendirilmesi (Yayınlanmamış doktora tezi). Karadeniz Teknik Üniversitesi, Eğitim Bilimleri Enstitüsü, Trabzon.

Parameswaran, R. (2007). On understanding the notion of limits and infinitesimal quantities. International Journal of Science and Mathematics Education, 5(2), 193-216.

Sierpinska, A. (1987). Humanities students and epistemological obstacles related to limits. Educational Studies in Mathematics, 18, 371-397. 
Singer, M., \& Voica, C. (2003, September). Perception of infinity: Does it really help in problem solving? Paper presented at the International Conference the Decidable and the Undecidable in Mathematics Education, Brno, Czech Republic.

Sönmez, V. ve Alacapınar, F. G. (2014). Örneklendirilmiş bilimsel araştırma yöntemleri (4. baskı). Ankara: Anı Yayıncilık.

Tall, D., \& Vinner, S. (1981). Concept image and concept definition in mathematics with particular reference to limits and continuity. Educational Studies in Mathematics, 12(2), 151-169.

Taşar, M. F., İngeç, Ş. K. ve Güneş, P. Ü. (2002, Ekim). Grafik çizme ve anlama becerisinin saptanmast. V. Ulusal Fen Bilimleri ve Matematik Eğitimi Kongresi’nde sunulan bildiri, Orta Doğu Teknik Üniversitesi, Ankara.

Travers, K. J., \& Westbury, I. (1989). The IEA study of mathematics I: Analysis of mathematics curricula. Elmsford, NY, US: Pergamon Press.

Tsamir, P., \& Dreyfus, T. (2002). Comparing infinite sets - A process of abstraction: The case of Ben. The Journal of Mathematical Behaviour, 21, 1-23.

Taşdemir, A., Demirbaş, M. ve Bozdoğan, A. E. (2005). Fen bilgisi öğretiminde işbirlikli öğrenme yönteminin öğrencilerin grafik yorumlama becerilerini geliştirmeye yönelik etkisi. Gazi Üniversitesi Kırşehir Eğitim Fakültesi, 6(2), 81-91.

Van Hiele, P. M. (1957). De problematick van het inzicht gedmonstreed van het inzicht van schodkindren in meetkundeleerstof [The problem of insight in connetcion with school children's insight into the subject matter of geometry] (Unpublished doctoral dissertation). University of Utrecht, Netherlands.

Williams, S. R. (1991). Models of limit held by college calculus students. Journal for Research in Mathematics Education, 22(3), 219-236. 